\title{
Dualism and Macroeconomic Volatility
}

\section{Citation}

Aghion, Philippe, Abhijit Banerjee, and Thomas Piketty. 1999. Dualism and macroeconomic volatility. Quarterly Journal of Economics 114(4): 1359-1397.

\section{Published Version}

doi:10.1162/003355399556296

\section{Permanent link}

http://nrs.harvard.edu/urn-3:HUL.InstRepos:4554124

\section{Terms of Use}

This article was downloaded from Harvard University's DASH repository, and is made available under the terms and conditions applicable to Other Posted Material, as set forth at http:// nrs.harvard.edu/urn-3:HUL.InstRepos:dash.current.terms-of-use\#LAA

\section{Share Your Story}

The Harvard community has made this article openly available.

Please share how this access benefits you. Submit a story.

\section{Accessibility}


DUALISM AND MACROECONOMIC VOLATILITY*

\author{
PhiLIPPE Aghion \\ AbHIJ IT BANERJ Ee \\ THOMAS PIKETTY
}

This paper develops a simple macroeconomic model that shows that combining capital market imperfections together with unequal access to investment opportunities across individuals can generate endogenous and permanent fluctuations in aggregate GDP, investment, and interest rates. Reducing inequality of access may be a necessary condition for macroeconomic stabilization. Moreover, countercyclical fiscal policies have a role to play: in our model savings are underutilized in slumps because of the limited debt capacity of potential investors. Therefore, the government should issue public debt during recessions in order to absorb those idle savings and finance investment subsidies or tax cuts for investors.

The most important single fact about saving and investment activities is that in our industrial society they are generally done by different people and for different reasons. (. . .) For years there might tend to be too little investment, leading to deflation, losses, excess capacity and unemployment. For other years, there might tend to be too much investment, leading to periods of chronic inflation-unless prudent and proper public policies in the fiscal and monetary fields are followed [Paul A. Samuelson, Economics 8th edition, 1970, pp. 196-198].

\title{
I. INTRODUCTION
}

The idea that the separation of savers and investors has implications for the short-run macroeconomic stability of an economy is an idea that goes back at least to Keynes [1936] and Harrod [1939]. This paper represents an attempt to address this question within the framework of a simple macroeconomic model with explicit micro-foundations.

* We are grateful to Pinar Bagci for research assistance; to seminar participants at University College London, London School of Economics, New York University, Harvard University, Massachusetts Institute of Technology, CEMFI (Madrid), the 1996 CEPR E conomic Theory Symposium in Gerzensee, the 1997 CEPR Macro Symposium in Athens, and in particular to Olivier Blanchard, Patrick Bolton, Ricardo Caballero, Peter Diamond, and the referees for helpful suggestions. We thank the McArthur F oundation and its "Cost of I nequality" group for financial support. The second author also acknowledges financial support from the National Science F oundation under grant number SBR-9422942.

(1) 1999 by the President and Fellows of Harvard College and the Massachusetts Institute of Technology.

TheQuarterlyJ ournal of Economics, November 1999 
In our model there are two dimensions of separation between savers and investors: sheer physical separation, manifested in the fact that savers and investors are often different people in the sense that many people who save are in no position to invest directly in physical (as distinct from financial) capital; and a more market-based separation embodied in the constraints on the amounts investors can borrow from savers.

We will justify the borrowing constraints by invoking the usual excuse of asymmetric information, modeled here as an ex post moral hazard problem. By a careful choice of parameters we ensure that the solution to this problem takes the extremely simple form of a credit multiplier. In other words, there is a constant $v<1$ such that anyone who wants to invest an amount I must have assets of at least $\nu{ }^{1}{ }^{1}$

There are a number of reasons why not all savers are also investors in the sense of being able to invest in physical capital. First, being able to invest may be crucially dependent on having certain skills, ideas, and connections: for the vast majority of individuals, the idea of using one's savings to borrow additional funds in order to open a new factory or purchase capital equipment makes no sense at all. Second, unequal access to investment opportunities may just be an extreme consequence of the credit constraints themselves: many investments are indivisible and require a certain minimum investment. In a world where capital markets are imperfect, this means that the investor would have to put up a minimum amount of his own wealth; those who cannot afford this minimum amount will not be able to make direct investments in production and will have to put their money in a bank that then lends their savings to active investors. Third, distances may limit the ability of investors to invest: the investment might require the investor to live and work in the city, whereas he may have other reasons for wanting tolive in a village. Investors may also be restricted by social distance: investing in most industries involves some degree of cooperation with investors in other industries and even with investors in other firms in the same industry. Therefore, if an industrial sector is dominated by people from one social group, and people from this social group are known to cooperate better with their own (perhaps for the

1. There is now a large body of evidence documenting that such borrowing constraints have large effects on investor behavior even in countries like the United States which have well-developed capital markets; see, for example, Fazzari, Hubbard, and Petersen [1988] and F azzari and Petersen [1993]. 
usual repeated-games reasons), outsiders may hesitate to invest in this sector. Finally, government regulations may restrict the ability of certain social groups to invest in certain assets. ${ }^{2}$

We model this physical separation of savers and investors by introducing an asset that we call activeinvestment (e.g., starting a firm) which has the highest return of all assets and which is only accessible to al ready existing businesses and their owners and to a fixed fraction of the labor force. We measure the separation by a constant $\mu$ which measures the share of labor income going to those who can actively invest (say, the managerial elite).

The main contribution of the paper is the development of a tractable framework for studying the business cycle implications of this kind of separation between savers and investors. The first result in the paper tells us that a high degree of such separation leads the economy to fluctuate around its steady-state growth path. More specifically, it is shown that under a condition that in our model turns out to take the very simple form of $\mu<\nu$, implying both a relatively high degree of physical separation of savers and investors and a poorly functioning capital market, the economy al ways converges to a cycle around its trend growth path unless $\mu$ is very small (or $v$ very large).

The logic behind the endogenous cycles is straightforward. Periods of slow growth are periods when savings are plentiful relative to the limited debt capacity of potential investors, which implies a low demand for savings and ther efore low equilibrium interest rates. This in turn implies that the investors can retain a high proportion of their profits (since the interest rate and hence the debt burden on investors is (ow), which allows them to rebuild their reserves and debt capacity and expand their investment. This, in turn, generates more profits and more investment until, eventually, planned investment runs ahead of savings forcing the interest rates to rise. Now the debt burden on the investors is going to be higher, retained earnings will be lower, and investment will collapse, taking us back to a period of slower growth.

It is worth noting that this endogenous cycle is a product of two distinct forces. On the one hand, high investment begets high profits and high investment. On the other, high investment pushes up interest rates and reduces future profits and investment. The first causes output to be positively serially correlated;

2. For example, in colonial India, under the Punjab Land Tenancy act, the colonial administration in the Punjab restricted the right to own land to certain "peasant" castes. 
the second generates a negative serial correlation. Depending on which of these forces dominates, the overall correlation of output may be positive or negative. In particular, we show that if credit constraints are severe and the fraction of active investors is low, then booms cannot last forever: in other words, the second force will eventually exhaust the debt capacity of investors and push the economy into recession.

It is also worth emphasizing that cyclical fluctuations in this world are always inefficient: the economy cycles because it has phases when savings are underutilized in the sense of being invested in an inferior asset. In this sense, our model partially captures the Keynesian idea that slumps are associated with a liquidity trap. ${ }^{3}$

Thecycle, however, is just one of three possibilities: if $\nu<\mu$, so that the degree of separation is low, we have a permanent boom; the economy converges to a stable growth path whereall available savings are always invested in the high-return activity. While if either $v$ is very high or $\mu$ is very low, the economy converges to a permanent slump in the sense of permanently underutilizing its saving.

Of these three cases the highest trend growth rates correspond, not surprisingly, to the permanent boom case; in this case the growth rate is exactly the Harrod-Domar growth rate. In both other cases the trend growth rate is always lower than the Harrod-Domar growth rate, but a priori we cannot tell which of the two rates is higher.

These threetypes of economies also differ in their response to shocks: where the degree of separation is low, that is, in what we have called a permanent boom economy, the full effect of a temporary productivity shock registers immediately in the output. When the degree of separation is higher, responses to shocks are more gradual, and therefore, there is more persistence in changes in output.

A permanent positive productivity shock raises the growth rate in a permanent boom economy, and the new higher growth rate is achieved immediately. By contrast, in a permanent slump economy the full impact of the shock on the growth rate comes about only gradually. The effect in the cyclical economy turns out

3. However, since we do not have a notion of liquidity in our model, we cannot capture the Keynesian idea that in a liquidity trap the inferior asset that savers hold is also a very liquid asset. 
to be more complex than in either of the two previous cases because one has to take account of the effect of higher interest rates generated by the positive productivity shock on the length of the subsequent slump. It turns out that in some cases a positive productivity shock can actually lower the average growth rate by prolonging the slump.

The overall picture that emerges from our analysis is that economies with less developed financial markets and a sharper physical separation between savers and investors will tend to be more volatile and to grow more slowly. For a number of obvious reasons both of these dimensions of separation are likely to be greater in emerging market economies (EMEs), which in turn may explain why macroeconomic volatility tends to be larger in these economies than in the more devel oped economies. ${ }^{4}$

However, there is at least some evidence that this kind of mechanism based on the functioning of the credit market is also relevant for understanding the business cycle properties of more devel oped economies.

For example, we believe that our analysis in this paper and in subsequent work by Aghion, Bacchetta, and Banerjee [1998] may shed somelight on the case of advanced market economies such as Finland, where financial devel opment (in terms of our parameter $v)$, however, is still lagging behind and which has experienced high macroeconomic volatility over the past decade (see H onkapohja and Koskela [1998]). And even in financially developed economies like the United States, the mechanism we describe in this paper may remain pertinent for the case of small investors whose investments turn out to be significantly correlated with current cash flows (see Bernanke, Gertler, and Gilchrist [1998]), and who therefore constitute a less financially developed enclave with the U.S. economy. The case for a credit channel in the transmission of shocks to theU. S. economy has been argued for in various contributions going back at least to the work of Haberler

4. Some reasons why the extent of separation of savers and investors may be especially large in EMEs include poor transportation facilities which exaggerate physical distances and limit certain types of investment to those who live close enough to the natural locale for the investment; badly defined and poorly enforced property rights make loan transactions harder; social segmentation, on the basis of caste and tribe, often acts to limit entry into specific industries; and high levels of social and economic inequality might mean that only a small fraction of the population has the wherewithal to be investors. 
$[1964]^{5}$ and more recently in a number of papers by Bernanke and Gertler. ${ }^{6}$

Given the inefficiency of cyclical fluctuations in our model, there is clearly a potential role for countercyclical macro policies. Since slumps are times where there are some idle savings that are not being used efficiently because of the limited debt capacity of potential investors, a natural strategy for recovery is to issue public debt in recessions in order to absorb those idle savings and finance investment subsidies or tax cuts for businesses. We show that under some conditions such policies can at the same time restore maximum growth and raise the savers' wel fare.

Of course, a different policy perspective on our model would be to argue that it stresses the importance of structural reforms that aim at reducing the extent of separation of savers and investors. This is especially likely to be important in situations where the appropriate countercyclical policies are difficult to carry out (for example, because the extent of separation is changing rapidly over time and in situations where countercyclical policies have adverse distributional consequences-the policies suggested by our model al ways help investors, but sometimes at the cost of savers). Structural reforms may in such cases be a necessary condition for the success of stabilization policies.

Our model is far from being the first that emphasizes the role of the separation between savers and investors as a source of macroeconomic volatility. This general point can be found in the works of Keynes [1936], Harrod [1939], among others, but in their models the primary source of instability is the exogenous instability in the investment rate.

Goodwin's [1967] model of growth cycles is closer to ours, in that it also describes cycles as the outcome of a dynamic process with the imbalance between investors and savers changing endogenously over time, although Goodwin's mechanism operates through the equilibrium wage rate rather than the equilibrium interest rate (for some evidence that our mechanism is important in practice, see subsection III.4). Despite this difference the two stories are entirely consistent with each other and share the common prediction that downturns in economic activity are

5. Who, in turn, refers to Hawtrey and Wicksell.

6. These authors have a number of papers of which perhaps the most immediately relevant is their recent survey of the literature [Bernanke and Gertler 1995a, 1995b). 
caused by the decline of investors' investment capacity. Where the papers differ most is in the modeling style. Unlike ours, Goodwin's model has no explicit micro-foundations and therefore does not allow for rigorous policy analysis and checks of robustness. In Appendix 2 we show how our model can easily be extended in order to offer a micro-founded version of a Goodwin cycle.

Our paper and all papers on the role of debt in the transmission of business cycles owe a lot to the seminal paper by Bernanke and Gertler [1995a], which, in turn, was influenced by the much older ideas of Fisher [1933] and his followers, on debt deflation. As in Bernanke and Gertler the presence of debt and borrowing in our model makes the effects of productivity and other shocks more persistent than they would otherwise be and also induces a multiplier with respect to these shocks. Where we go beyond Bernanke and Gertler is in emphasizing the general equilibrium effects of such shocks: a shock that increases profits now will increase debt capacity and therefore investment in the future, but it will also raise interest rates and the debt burden which discourages investment. Therefore, in the medium run, investment might go down rather than up as a result of the increase in profits. It is this general equilibrium mechanism that allows our model, unlike that of Bernanke and Gertler, to have oscillations and endogenous cycles.

General equilibrium effects also play a role in the paper by Kiyotaki and Moore [1997] on the business cycle effects of borrowing constraints. In their paper a shock to profits raises investment which, in turn, increases the price of collateral which makes the investors (who already own collateral) richer and induces more investment. Of course, this process is accompanied by an increase in the debt burden, but the increase in the debt burden is matched by the increase in profits coming from the extra investment that caused the debt to go up in the first place: unlike in our model there is no interest rate effect that would cause the debt burden to go up disproportionately. Consequently, in their basic model the credit market effects only amplify and draw out the initial shock: there is no endogenous counteracting effect of the kind that we emphasize and that give us the endogenous oscillations. Such a counteracting effect, which causes the economy to have persistent oscillations in response to a shock, does appear in a generalized version of their model, but in order to have it, they need to introduce lags in the response of investment to changes in 
borrowing capacity. Whilesuch lags may well be plausible, it is not clear to what extent it is the lags rather than the basic mechanisms of the model that are driving the cycles. ${ }^{7}$ Moreover, they only report damped oscillations and do not provide us with conditions under which the model will converge to a limit cycle.

Finally, our focus on the interplay between credit imperfections and the dynamics of distribution relates this work to the literature on inequality, credit-market imperfections, and growth (see, e.g., Banerjee and Newman [1993], Galor and Zeira [1993], Aghion and Bolton [1997], and Piketty [1997]). However, the emphasis on short-run fluctuations directs our attention toward a very different kind of inequality than the one emphasized in this literature. We find that from the point of view of short-run stability, it is the inequality between savers and investors, rather than the inequality between the rich and the very poor (who neither invest nor save very much) that matters.

The paper is organized as follows. Section II outlines the basic framework. In Section III the basic model is analyzed, and the basic results about stability and the nature of the response to shocks are derived. Section IV discusses the impact of government policies on volatility and average growth.

\section{BASIC FRAMEWORK}

The economy has one nonproduced input (labor) and one produced good, which serves both as a capital input and as a consumption good. Each agent is endowed with one unit of labor at each period.

Technology. The production function for the one produced good is $F(K, L)=A K^{\beta} L^{1-\beta}=Y$. In order to focus our attention upon the capital market equilibrium, we assume that the labor market takes a very simple form: the wage rate is permanently equal to

7. Freixas and Rochet [1997] have a discussion of the Kiyotaki-M oore paper where they claim that it can be adapted to have oscillations even without the lags, by adding an alternative use for the collaterizable asset. In their version of the model, as the amount of borrowing grows and more and more of the collaterizable asset gets used in the production sector, less and less of it goes to the alternative use. This reduces profits because the alternative use is actually more profitable than production. However, this seems to rely on the investors not optimizing; otherwise they would al ways put the asset to its most profitable use rather than use it for increasing production. 
one, and firms can always hire as much labor as they wish to at that price. ${ }^{8}$ In equilibrium,

$$
\begin{array}{rll}
\frac{\partial \mathrm{F}}{\partial \mathrm{L}}=1 & \Rightarrow \quad \mathrm{L}=((1-\beta) \mathrm{A})^{1 / \beta} \mathrm{K} \\
& \Rightarrow \quad \mathrm{Y}=\sigma \mathrm{K} \\
& \text { with } \left.\quad \sigma=\mathrm{A}((1-\beta) \mathrm{A})^{(1-\beta) / \beta}\right) .
\end{array}
$$

This is an example of what has been called an AK model and therefore will generate positive long-run growth. Also note that the labor and capital shares of final output are given by the usual formulas: $(\partial \mathrm{Y} / \partial \mathrm{L}) \mathrm{L}=(1-\beta) \sigma \mathrm{K}$ and $(\partial \mathrm{Y} / \partial \mathrm{K}) \mathrm{K}=\beta \sigma \mathrm{K} .{ }^{9}$

Investment Possibilities. Not everyone has direct access to investments in production. Those who cannot invest directly in production (the "noninvestors," or the "lenders," or "savers") can either lend at the current interest rater to those who can invest in production (the "investors," or the "borrowers") or invest in a low-yield asset that yiel ds a return $\sigma_{2}$, with $\sigma_{2}<\sigma_{1}=\beta \sigma .{ }^{10}$ We will think of this asset as storage, but it could as well be some other production technology (or some government bond; see Section IV below). In addition to firms' owners, the investors' class also includes a fixed fraction of the labor force (say, the managers who have sufficient knowledge about direct investment opportunities), and the size of this group is measured by its share $\mu$ in total labor income. The case $\mu=0$ is the case where all productive investment is carried out directly by businesses and their owners and the "household sector" can only lend its savings to the "business sector" (or invest in the low-yield asset). At the other extreme, the case $\mu=1$ is the case where everyone can directly invest his own

8. Therefore, we are implicitly assuming that the size of the labor force grows at least as fast as the capital stock, such that the wage rate is fixed to one for standard labor supply reasons (agents are prepared to sell their labor unit at any price higher than or equal to one).

9. Instead of assuming an unlimited labor supply at price 1 , one could also assume a fixed labor supply $L_{0}$ and introduce an aggregate capital accumulation externality à la Frankel [1962] or Romer [1986] in order to obtain an AK model with steady-state long-run growth: if $Y=A K^{\beta} L^{1-\beta} K_{a}^{\gamma}$, where $K_{a}$ is the aggregate capital stock (the effects of which are not internalized by individual firms), then if $\gamma=1-\beta$ and $L \equiv L_{0}$, we have $Y=\sigma \mathrm{K}$, with $\sigma=A L_{0}^{1-\beta}$, and the capital share (respectively, the labor share) of output is again equal to $\beta Y$ (respectively, $(1-\beta) Y)$. These alternative assumptions would leave our analysis of macroeconomic volatility unaffected, while extending it beyond the Harrod-Domar case to the case of more standard AK technologies.

10. We assume the financial intermediation process between lenders and investors to be perfectly competitive, so that lenders always get the full return to their savings. This allows us to avoid dealing with the banking sector in what follows. 


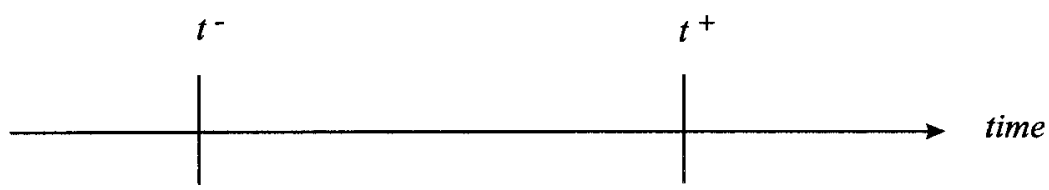

- Investment Decisions

- Lending vs. "Storage"
- Returns

- Debt - Repayment

- Consumption / Savings

FIGURE I

The Timing

savings into the high-yield production activity and where there is thus no separation between savers and investors.

Capital Market Imperfection. Due to standard incentivecompatibility considerations, an investor with initial wealth $\mathrm{W}$ can invest at most $\mathrm{W} / v$, where $1 / v>1$ is a credit multiplier. ${ }^{11}$ Credit constraints vanish as $v$ tends toward 0 , while $v=1$ is the polar case where the credit market collapses and investors can only invest their own wealth.

Determination of the Interest Rate. The interest rate is the one price in this model that is determined endogenously. The linearity of the production technology implies that the equilibrium interest rate will be exactly equal to the rate of return $\sigma_{1}=$ $\beta \sigma$ whenever planned investment in production is higher than aggregate savings, and it will drop down to $\sigma_{2}$ in the opposite case (see bel ow). ${ }^{12}$ Our results can be extended to a more general model where the interest rate changes smoothly over time (see subsection III.4 below).

The Timing of Events. The timing of events within in each period $t$ is depicted in Figurel.

Borrowing and lending take place at the beginning of the period (which we denote by $\mathrm{t}^{-}$), at an interest rate that is

11. An explicit microeconomic derivation of this (constant) credit multiplier is developed in Appendix 1, where we also discuss the robustness of our analysis to alternative microeconomic foundations whereby the multiplier $v$ ends up depending upon the interest rater. See also our discussion in subsection III .4 below.

12. Throughout the paper we will adopt the convention that interest rates as well as the growth rates refer to the gross rate (i.e., one plus the net rate). 
determined as indicated above by the comparison between planned investments and savings at $\mathrm{t}^{-}$.

Everything else occurs at the end of the period (which we denote by $\mathrm{t}^{+}$): first, the returns to investments are realized; second, the repayment of debt from borrowers to lenders; third, the consumption decisions and the savings decisions that in turn will determine the total amount of available savings at the beginning of next period (i.e., at $\left.(t+1)^{-}\right)$.

Savings Behavior. For simplicity, we assume a linear saving behavior: all agents save a fixed fraction $(1-\alpha)$ of their total end-of-period wealth and consume a fixed fraction $\alpha$ (see subsection III.4 bel ow for a discussion of alternative assumptions).

Now that the model has been fully laid out, we can analyze the dynamics of the underlying economy and, in particular, try to understand why the inequality in investment opportunities between investors and noninvestors, in other words the separation between savings and investments, can generate macroeconomic volatility.

\section{The Mechanics of the Model}

\section{III.1. The Basic Dynamic Relationships}

Let $\mathrm{W}_{\mathrm{B}}^{\mathrm{t}}$ and $\mathrm{W}_{\mathrm{L}}^{\mathrm{t}}$ denote the wealth of investors (borrowers) and noninvestors (lenders) at the beginning of period $(t+1)$. Total savings from previous period $t$ are by definition equal to

$$
\mathrm{S}_{\mathrm{t}}=\mathrm{W}_{\mathrm{B}}^{\mathrm{t}}+\mathrm{W}_{\mathrm{L}}^{\mathrm{t}} \text {. }
$$

Total planned investments in the high-yield activity at the beginning of period $(t+1)$ are equal to

$$
\mathrm{I}_{\mathrm{t}+1}^{\mathrm{d}}=\mathrm{W}_{\mathrm{B}}^{\mathrm{t}} / \nu \text {. }
$$

Note the following.

1. The interest rate $r_{t+1}$ in period $(t+1)$ is equal to $\beta \sigma=\sigma_{1}$ if $\mathrm{I}_{\mathrm{t}+1}^{\mathrm{d}}>\mathrm{S}_{\mathrm{t}}$ (that is, whenever the investment capacity of investors is higher than aggregate savings) and to $\sigma_{2}$ if $\mathrm{I}_{\mathrm{t}+1}^{\mathrm{d}}<\mathrm{S}_{\mathrm{t}}$ (that is, whenever the investment capacity of investors is lower than aggregate savings).

2. Actual investment in the high-yield activity at date $(t+1)$ is equal to $\min \left(S_{t}, I_{t+1}^{d}\right)$, whereas investment in the lowyield activity (with return $\sigma_{2}$ ) is equal to $S_{t}-\min \left(S_{t}, I_{t+1}^{d}\right)$. 
3. Current borrowing by investors is equal to the difference between actual investment in the high-yield activity and their initial wealth $W_{B}^{t}$.

During periods when investment demand is higher than aggregate savings, all savings are invested in the high-yield activity (with total return $\sigma$ ) and the growth rate of the economy takes its maximum value $g^{*}=(1-\alpha) \sigma \cdot{ }^{13}$ We will call these periods "booms." Conversely, during periods when investment demand is less than aggregate savings, a positive fraction of aggregate savings is invested in the low-yield activity so that the growth rate is smaller than $g^{*}$. We will call these periods "slumps." We can now obtain the following equations describing the dynamic evolution of capital accumulation between two consecutive periods. During a boom (i.e., if $\mathrm{I}_{\mathrm{t}+1}^{\mathrm{d}}>\mathrm{S}_{\mathrm{t}}$ ),

(B) $\mathrm{W}_{\mathrm{B}}^{\mathrm{t}+1}=(1-\alpha)\left[\mu(1-\beta) \sigma\left(\mathrm{W}_{\mathrm{B}}^{\mathrm{t}}+\mathrm{W}_{\mathrm{L}}^{\mathrm{t}}\right)\right.$

$$
\begin{array}{r}
\left.+\beta \sigma\left(W_{B}^{t}+W_{L}^{t}\right)-\beta \sigma W_{L}^{t}\right] \\
W_{L}^{t+1}=(1-\alpha)\left[(1-\mu)(1-\beta) \sigma\left(W_{B}^{t}+W_{L}^{t}\right)+\beta \sigma W_{L}^{t}\right] .
\end{array}
$$

In other words, given that all available savings $\left(W_{B}^{t}+W_{L}^{t}\right)$ are invested in the high-yield activity during a boom, total revenue from this activity is equal to $\sigma\left(\mathrm{W}_{\mathrm{B}}^{\mathrm{t}}+\mathrm{W}_{\mathrm{L}}^{\mathrm{t}}\right)$. A fraction $(1-\beta)$ of that revenue remunerates the labor force, with investors (respectively, noninvestors) representing a fraction $\mu$ (respectively, $1-\mu$ ) of the total labor share of output. Second, while borrowers realize the yield rate of return $\beta \sigma$ on capital investment $\left(W_{B}^{t}+W_{L}^{t}\right)$, they must repay the high interest rate $r=\beta \sigma$ on the amount $W_{L}^{t}$ they have borrowed from the lenders (hence the term $-\beta \sigma \mathrm{W}_{\mathrm{L}}^{\mathrm{t}}$ in the right-hand side of the first equation, which corresponds to the term $\beta \sigma \mathrm{W}_{\mathrm{L}}^{\mathrm{t}}$ in the right-hand side of the second equation).

Similarly, during a slump (i.e., if $\mathrm{I}_{\mathrm{t}+1}^{\mathrm{d}}<\mathrm{S}_{\mathrm{t}}$ ),

$$
\text { (S) } \begin{aligned}
\mathrm{W}_{\mathrm{B}}^{\mathrm{t}+1} & =(1-\alpha)\left[\mu(1-\beta) \sigma \cdot \frac{1}{v} \mathrm{~W}_{\mathrm{B}}^{\mathrm{t}}+\beta \sigma \frac{1}{v} \mathrm{~W}_{\mathrm{B}}^{\mathrm{t}}-\sigma_{2}\left(\frac{1}{v}-1\right) \mathrm{W}_{\mathrm{B}}^{\mathrm{t}}\right] \\
\mathrm{W}_{\mathrm{L}}^{\mathrm{t}+1} & =(1-\alpha)\left[(1-\mu)(1-\beta) \sigma \cdot \frac{1}{v} \mathrm{~W}_{\mathrm{B}}^{\mathrm{t}}+\sigma_{2} \mathrm{~W}_{\mathrm{L}}^{\mathrm{t}}\right] .
\end{aligned}
$$

Namely, given that only the amount $\mathrm{W}_{\mathrm{B}}^{\mathrm{t}} / \nu$ can be invested in

13. $\mathrm{g}^{*}$ is the standard Harrod-Domar growth rate, i.e., the product of the savings rate by the output/capital ratio. 
the high-yield activity during a slump, this activity will generatea revenue equal to $\sigma \mathrm{W}_{\mathrm{B}}^{\mathrm{t}} / \nu$. A fraction $(1-\beta)$ of that revenue remunerates labor, with borrowers (respectively, lenders) getting a fraction $\mu$ (respectively, $1-\mu$ ) of that revenue. The fraction $\beta$ of that revenue remunerates capital investment and thus accrues entirely to the borrowers. However, borrowers must pay the interest rate $\sigma_{2}$ on the amount $\left(\mathrm{W}_{\mathrm{B}}^{\mathrm{t}} / v-\mathrm{W}_{\mathrm{B}}^{\mathrm{t}}\right)$ they borrow from the middle-class lenders. On the other hand, lenders realize the rate of return $\sigma_{2}$ on their wealth $\mathrm{W}_{\mathrm{L}}^{\mathrm{t}}$, both by lending a fraction of it to wealthy borrowers and by investing the complementary fraction in the low-yield activity. ${ }^{14}$

Letting $\mathrm{q}^{\mathrm{t}}=\mathrm{S}_{\mathrm{t}} / /_{\mathrm{t}+1}^{\mathrm{d}}$ denote the ratio of savings over planned investments in the high-yield activity at the beginning of period $(t+1)$, simple manipulation of the above equations leads to

$$
\frac{1}{\mathrm{q}^{\mathrm{t}+1}}=\frac{\mu(1-\beta)}{v}+\beta \cdot \frac{1}{\mathrm{q}^{\mathrm{t}}},
$$

when $\mathrm{q}^{\mathrm{t}} \leq 1$ (i.e., when the economy is in a boom at the beginning of period $t+1)$ and

$$
\mathrm{q}^{\mathrm{t}+1}=\frac{1}{\mu(1-\beta)(\sigma / v)+(1 / v) \beta \sigma-((1 / v)-1) \sigma_{2}}\left[\left(\sigma-\sigma_{2}\right)+\sigma_{2} \mathrm{q}^{\mathrm{t}}\right],
$$

when $q^{t}>1$ (i.e., when the economy is currently experiencing a slump).

Equations $\left(\mathrm{B}^{\prime}\right)$ and $\left(\mathrm{S}^{\prime}\right)$ define a simple first-order difference equation which allows a complete characterization of the global dynamics of the economy.

\section{III.2. Slumps and Booms}

Note first that both curves $\left(\mathrm{B}^{\prime}\right)$ and $\left(\mathrm{S}^{\prime}\right)$ are monotonically increasing and intersect the $45^{\circ}$ degree line only once (from above). Note also that the $\left(\mathrm{B}^{\prime}\right)$-curve always lies above the $\left(\mathrm{S}^{\prime}\right)$-curveat $\mathrm{q}^{\mathrm{t}}=1: \mathrm{q}^{\mathrm{t}+1}\left(\mathrm{q}^{\mathrm{t}}=1, \mathrm{r}_{\mathrm{t}+1}=\sigma_{1}\right)>\mathrm{q}^{\mathrm{t}+1}\left(\mathrm{q}^{\mathrm{t}}=1, \mathrm{r}_{\mathrm{t}+1}=\sigma_{2}\right) \cdot{ }^{15}$

14. They lend the amount $\left(\mathrm{W}_{\mathrm{B}}^{\mathrm{t}} / v-\mathrm{W}_{\mathrm{B}}^{\mathrm{t}}\right)$ to the high-yield investors and invest the remaining amount $\mathrm{W}_{\mathrm{t}}^{\mathrm{t}}-\left(\mathrm{W}_{\mathrm{B}}^{\mathrm{t}} / v-\mathrm{W}_{\mathrm{B}}^{\mathrm{t}}\right)$ in the low-yield activity.

15. The intuition for this is quite straightforward: borrowers benefit from lower interest rates at the expense of lenders. Therefore, the savings/investment demand ratio is lower next period if the current interest rate $r_{t+1}$ is lower, for a given allocation of funds (if $\mathrm{q}^{\mathrm{t}}=1$, all savings are invested in the high-yield activity, irrespective of whether $r_{t+1}=\sigma_{1}$ or $\sigma_{2}$ ). M ore formally, when $q^{t}=1$,

$$
q^{t+1}\left(q^{t}=1, r_{t+1}=\sigma_{2}\right)=\frac{1}{(\mu(1-\beta) / v)+(\beta / \nu)-((1 / v)-1)\left(\sigma_{2} / \sigma\right)}
$$


Therefore, thereare only three possible cases corresponding to the three possible rankings between $1, s$, and $b$, where $s$ and $b$ are the intersections of the $\left(\mathrm{S}^{\prime}\right)$ and $\left(\mathrm{B}^{\prime}\right)$ curves with the $45^{\circ}$ line. These are depicted in Figures II, III, and IV.

Figure II corresponds to the case where $1>b(>s)$. In this case, as is evident from the figure, the economy converges to a permanent boom with $\mathrm{q}_{t} \rightarrow \mathrm{b}$. The long-run growth rate for the economy is just the Harrod-Domar growth rate $g^{*}=(1-\alpha)_{\sigma}$. Simple manipulation of equation $\left(\mathrm{B}^{\prime}\right)$ yields

$$
\mathrm{b}=v / \mu \text {. }
$$

The condition $b<1$ is therefore equivalent to $v<\mu$. This necessary and sufficient condition is very intuitive: a permanent boom will occur when the fraction of the labor force that has direct access to investments in production is sufficiently largeto compensate for the borrowing constraints faced by these investors. This condition ensures that in the long run the debt capacity of investors will always be sufficient for all available savings to be absorbed and invested in the high-yield activity. In particular, the Harrod-Domar permanent boom regime will occur if credit constraints are negligible ( $v$ close to 0 ) or if all agents have direct access to productive investments ( $\mu$ close to 1 ). Conversely, permanent booms will never occur if $\mu=0$; i.e., if business profits are the only investible funds. This is because if $\mu=0$, then the investment capacity of the economy grows at rate $(1-\alpha) \beta \sigma$ while savings grow at the higher rate $(1-\alpha)_{\sigma}$ : the latter will therefore al ways be in excess supply after some finite time. ${ }^{16}$ The condition $\mu>v$ also shows that both dimensions of separation between investors and savers (i.e., $v>0$ and $\mu<1$ ) are necessary in order to generate slumps in the long run.

Figure III corresponds to the case where $1<\mathrm{s}(<\mathrm{b})$. Here, the economy always converges to a permanent slump (with $\mathrm{q}^{\mathrm{t}} \rightarrow \mathrm{s}$ ), and with a rate of growth that is less than the Harrod-Domar

\footnotetext{
$$
<\mathrm{q}^{\mathrm{t}+1}\left(\mathrm{q}^{\mathrm{t}}=1, \mathrm{r}_{\mathrm{t}+1}=\sigma_{1}\right)=\frac{1}{(\mu(1-\beta) / v)+\beta} .
$$

$\left(\sigma_{1}=\beta \sigma>\sigma_{2}\right.$ implies that $\left.\left.\beta<(\beta / v)-(1 / v)-1\right)\left(\sigma_{2} / \sigma\right)\right)$.

16. If $\mu>0$, then the investment capacity of the economy grows at rate $(1-\alpha) \cdot(\mu(1-\beta) \sigma) / v)+\beta \sigma)$, which is smaller than the savings growth rate iff $\mu<v$.
} 


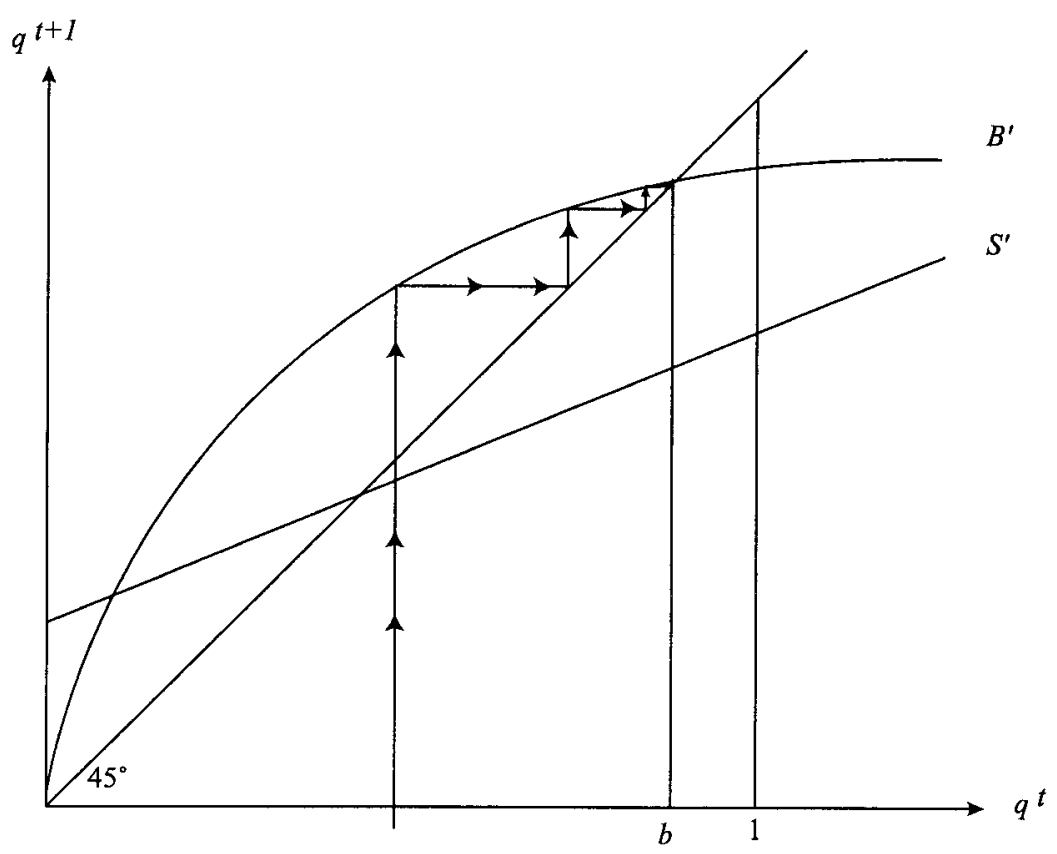

FIGURE II

The Permanent Boom Regime

growth rate $(1-\alpha)_{\sigma}$. Simple manipulation of equation $\left(\mathrm{S}^{\prime}\right)$ yields

$$
\mathrm{s}=\frac{\left(\sigma-\sigma_{2}\right) \nu}{\mu(1-\beta) \sigma+\beta \sigma-\sigma_{2}} .
$$

The necessary and sufficient condition defining the permanent slump regime is then given by

$$
\mathrm{s}<1 \text {, or equivalently, } \mu(1-\beta)+\beta<v+\frac{\sigma_{2}}{\sigma}(1-v) .
$$

This condition is also very intuitive: permanent slumps will tend to occur when the credit multiplier is small ( $v$ high) and few people have direct access to investments in production ( $\mu$ small). Noteal so that permanent slumps are more likely to occur if $\sigma_{2} / \sigma$ is high: a high $\sigma_{2} / \sigma$ ratio implies high debt repayment/profit ratios for investors and therefore makes it less likely that their debt capacity will ever be able to absorb all available savings (the same reasoning applies if the capital share $\beta$ is low). The expression for 


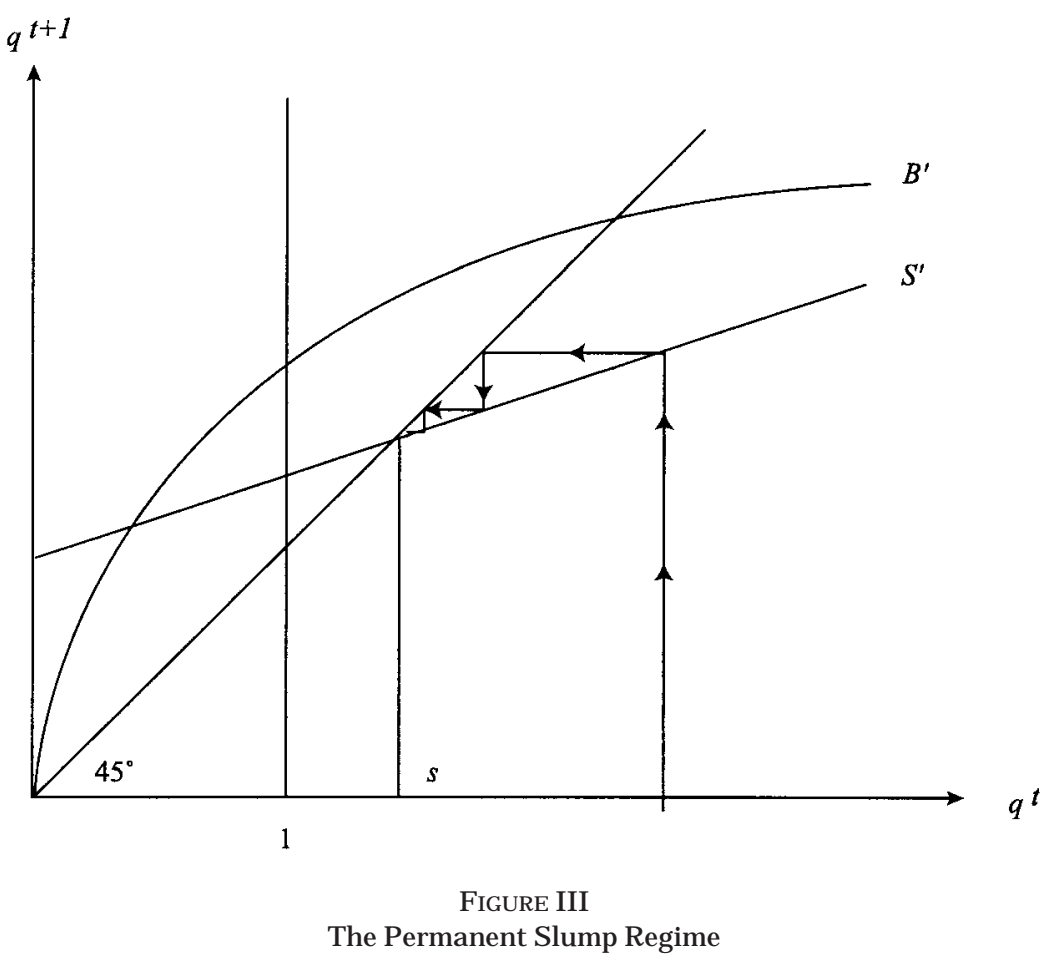

$s$ can also be used to compute the exact growth rate $g_{s}$ associated with the permanent slump regime: in steady state a fraction $1 / \mathrm{s}$ of aggregate savings is invested in the high-yield activity (with return $\sigma$ ), while the remaining fraction $1-1 / s$ is invested in the low-yield activity (with return $\sigma_{2}$ ), so that the steady-state growth rate $g_{s}$ is given by

$$
\begin{aligned}
g_{s} & =(1-\alpha)\left(\frac{1}{s} \sigma+\left(1-\frac{1}{s}\right) \sigma_{2}\right) \quad(<(1-\alpha) \sigma) \\
& =(1-\alpha)\left(\sigma_{2}+\frac{\mu(1-\beta) \sigma+\beta \sigma-\sigma_{2}}{v}\right) .
\end{aligned}
$$

This is al ways lower than the Harrod-Domar growth rate.

Figure IV corresponds to the case wheres $<1<\mathrm{b}$. In this case the figure shows that the economy keeps moving back and forth between booms and slumps and will eventually converge to a limit-cycle. Thetwo conditions for this case are $\beta+(1-\beta) \mu>v+$ 


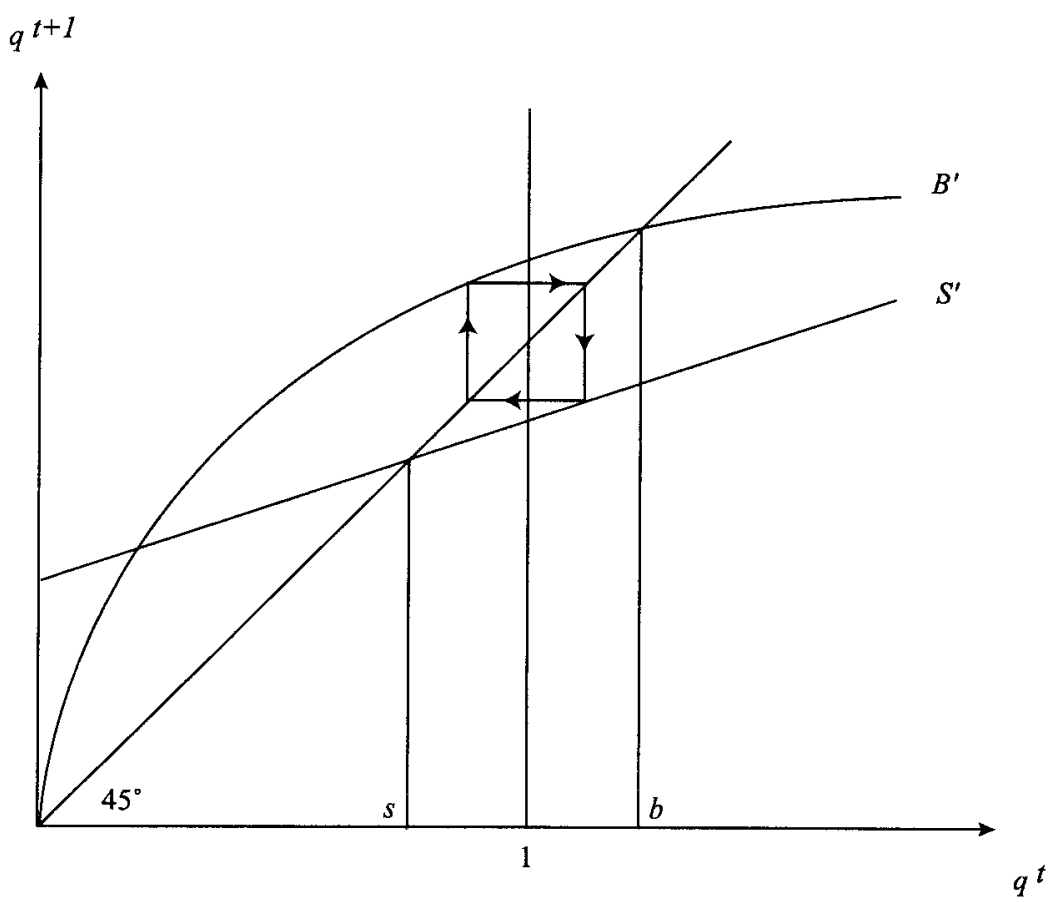

FIGURE IV

The Cycles Regime

$\left(\sigma_{2} / \sigma\right)(1-\nu)$ and $\mu<\nu$. These two conditions imply that an economy with a very high degree of separation between savers and investors as well as an economy where both groups are extremely well integrated will not cycle: in the first case there will be a permanent slump and in the second a permanent boom. ${ }^{17}$ It is only in the intermediate case where the separation is large but not too large that we observe short-run instability. Note that shortrun instability is associated with the economy performing below its potential (as measured by growth rates), since slumps are phases where some of the capital is put to less than optimal use: the growth rate is equal to the Harrod-Domar growth rate during booms (when $\mathrm{q}^{\mathrm{t}}<1$ ) but is strictly below the Harrod-Domar growth rate during recessions (when $\mathrm{q}^{\mathrm{t}}>1$ ).

17. In particular, a highly underdeveloped economy where businesses rely entirely on their own retained earnings to invest will not cycle. 


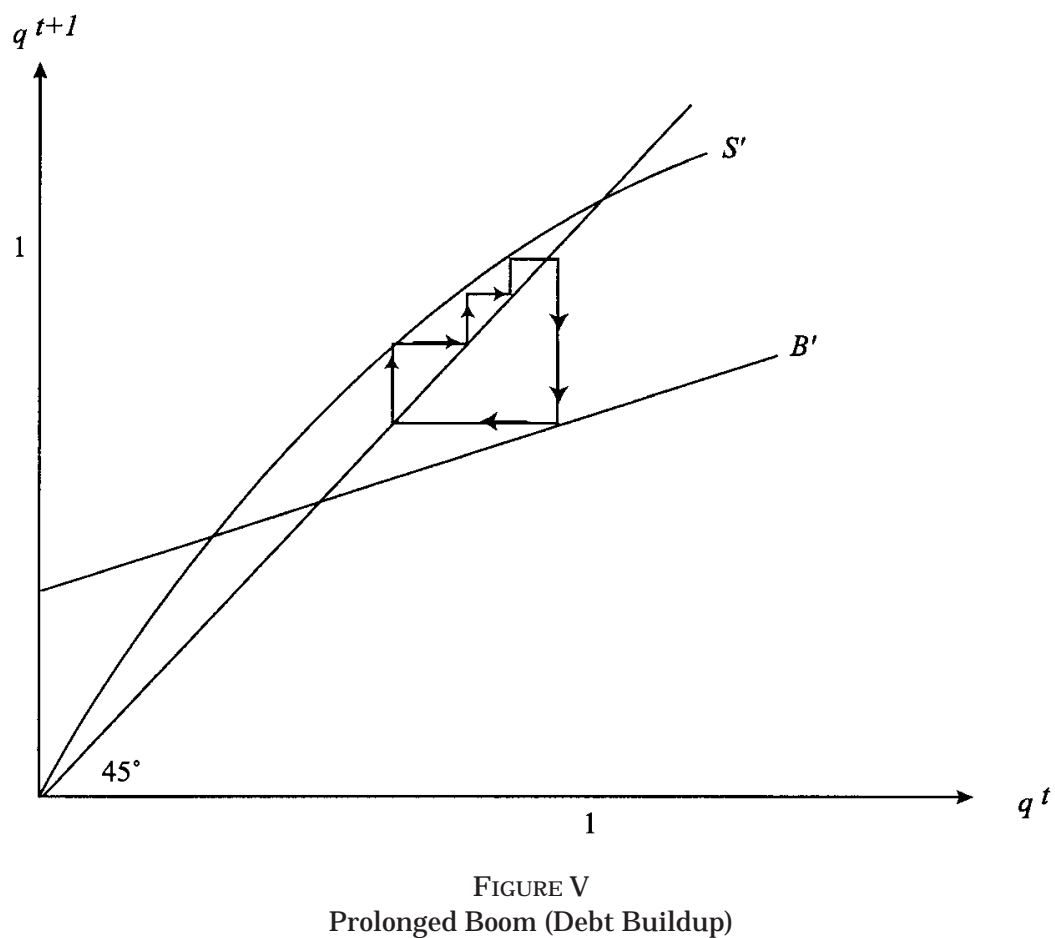

Note also that the limit cycle need not be a two-cycle as depicted in Figure IV. Figures V and VI depict $n>2$-cycles, with either a debt-buildup phase during which borrowers are getting poor relative to creditors (Figure $\mathrm{V})^{18}$ or a profit-reconstitution phase during which borrowers are getting richer relative to creditors-both because creditors get the low rate $\sigma_{2}$ on their savings and because borrowings are low during slumps (Figure VI). ${ }^{19}$ The relative length of boom (i.e., debt buildup) and slump (i.e., profit reconstitution) phases will depend upon the basic parameters of the model: expansionary phases with debt buildup will last longer when the slope of the $\left(\mathrm{B}^{\prime}\right)$ curve at the point $\mathrm{b}$ is close to 1 (or equivalently, when $\beta$ is close to 1 ); on the other hand,

18. This case is more likely to arise when the slope of the $\left(\mathrm{B}^{\prime}\right)$-curve is sufficiently close to 1 at $b$; that is, when $\beta$ is close to 1 .

19. This case is more likely to arise when the slope of the $\left(S^{\prime}\right)$-curve is sufficiently close to 1 ; i.e., when

$$
(1 / v)\left[\sigma_{2}-(\mu(1-\beta)+\beta)\right]
$$

is sufficiently small. 


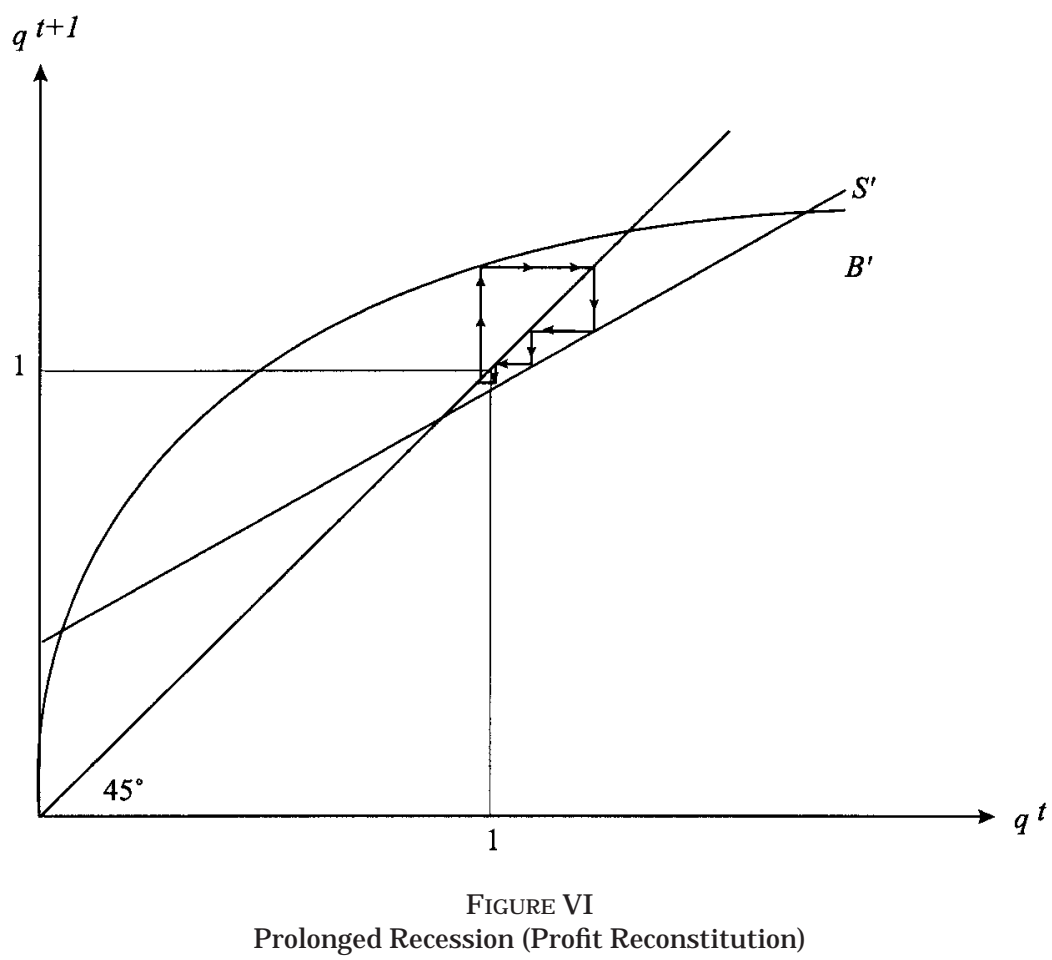

the length of recession phases will go up when the slope of the $\left(\mathrm{S}^{\prime}\right)$-curve gets closer to 1 (in particular when $v$ or $\sigma_{2}$ is large as in Figure VI).

Intuitively, during an expansionary phase, investment (and therefore borrowings) will go up since output and profits, and therefore the borrowing capacity of investors, are growing. And the higher the share of capital $\beta$ in the revenue from the high-yield activity, the more will profits increase over time and therefore the longer will the investors' borrowing capacity keep on absorbing total savings. Hence the higher $\beta$, the longer the debt buildup phases. On the other hand, the larger $\sigma_{2}$ or $v$, the larger the ratio of savings over planned investment when the economy enters a recession; this, together with the fact that investors must repay a higher interest rate $\sigma_{2}$ to their lenders throughout the recession, implies that it will take longer before the borrowing capacity of investors can again absorb the totality of savings (at which point the economy can reenter a boom). 


\section{III.3. The Effects of Shocks}

How does such an economy react to shocks? In order to answer this question, we first look at how the shocks movethe two curves $\left(\mathrm{B}^{\prime}\right)$ and $\left(\mathrm{S}^{\prime}\right)$. We will focus on two kinds of shocks: shocks to $\sigma$, which are naturally interpreted as productivity shocks and shocks to $\sigma_{2}$, which may be thought of either as productivity shocks (for example, if this asset is thought of as home production) or as policy shocks (for example, if this asset is thought of as money, the shock could be a change in the variance of the inflation rate).

It is easy to see from equation $B^{\prime}$ that the curve $\left(B^{\prime}\right)$ is unaffected by changes in $\sigma$ and $\sigma_{2}$. This should be intuitive: an increase in $\sigma$ during a boom increases both the return to investment and the return on savings exactly in the same proportion and therefore does not affect the distribution of wealth between the savers and investors (measured by q). A change in $\sigma_{2}$ has no effect because in a boom no one puts his money in the inferior asset.

A trivial calculation establishes that in the range in which the ( $\mathrm{S}^{\prime}$ ) curve is relevant (i.e., as long as $q>1$ ), an increase in $\sigma$ and a fall in $\sigma_{2}$ lowers the $\left(\mathrm{S}^{\prime}\right)$ curve. This too should be intuitive: in a slump an increase in $\sigma$ benefits the investors but not the savers, while a fall in $\sigma_{2}$ hurts the savers while benefiting the investors.

It follows that if the economy is in a permanent boom, neither a temporary nor a permanent shock to productivity (i.e., $\sigma$ going up) has any effect on the distribution of wealth between savers and investors. It does of course have an effect on the rate of growth: in periods where $\sigma$ is higher, the growth rate will be proportionally higher. However, because there is no effect on $q$, the entire effect on the growth rate is registered in the period of the shock. In other words, if the shock is permanent, the economy immediately goes to its steady-state growth rate; and if it is temporary, after the shock, the economy grows at the same rate as before the shock, al beit starting at a higher level of GNP. Changes in $\sigma_{2}$ have no effect for obvious reasons. Figure VII a (respectively, VIIb) describes the dynamic effects of a permanent (respectively, temporary) increase in $\sigma$ on the growth rate when the economy is-and remains-in a permanent boom. ${ }^{20}$

The picture in a permanent slump economy is quite different.

20. In this and the following figures, we assume for simplicity that the economy is initially at a steady state. 


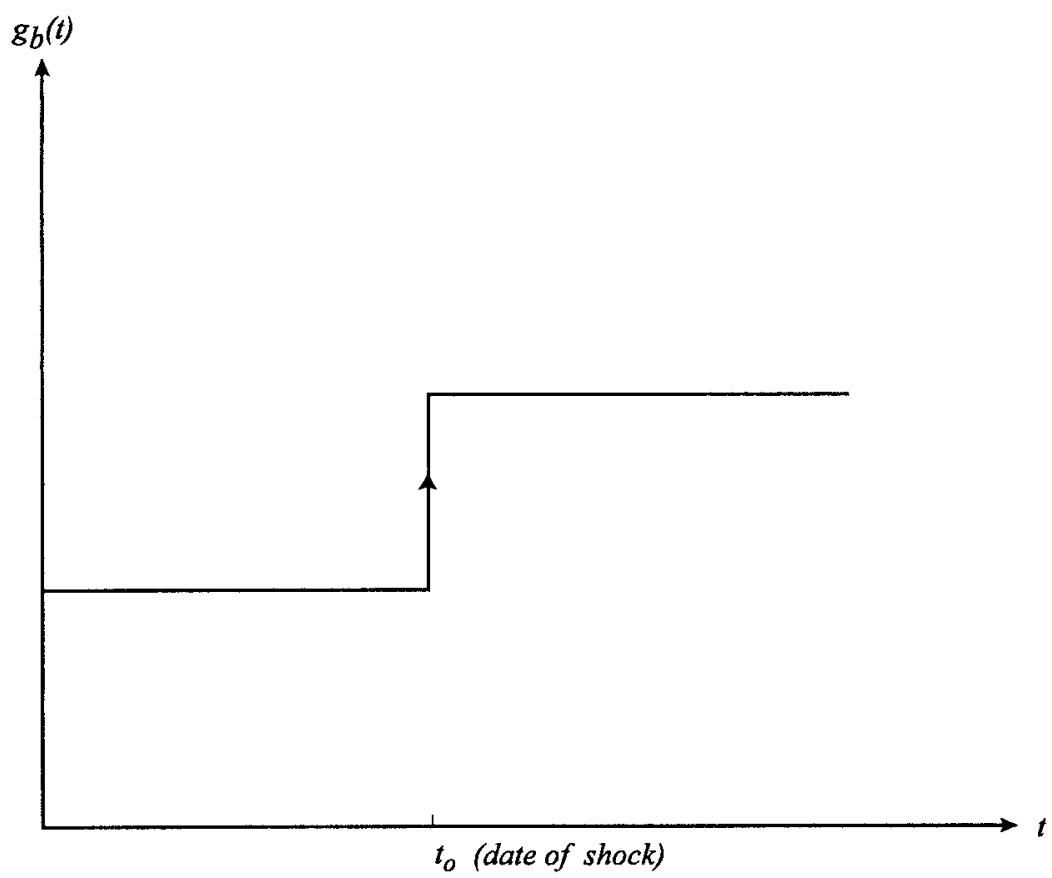

FIGURE VIIa

Effect of a Permanent Increase in $\sigma$ on a Booming E conomy

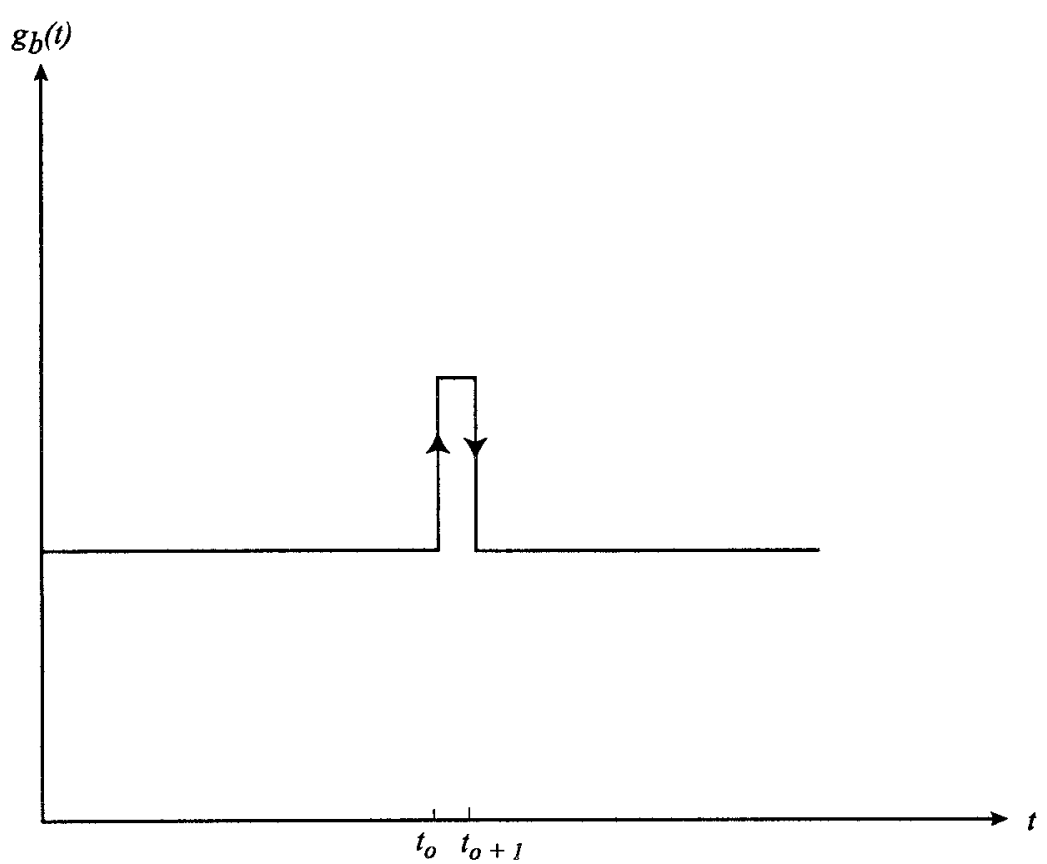

FIGURE VII b

Effect of a Temporary I ncrease in $\sigma$ on a Booming E conomy 
Note first that the steady-state growth rate $g_{s}$ is an increasing function of $\sigma$ but a decreasing function of $\sigma_{2}$ : that is, the positive effect of a higher $\sigma_{2}$ on the returns to the fraction of savings that are not invested in the high-yield activity is more than offset by the negative effect of a higher $\sigma_{2}$ on debt repayments and therefore on the steady-state debt capacity of investors. Taxing $\sigma_{2}$ and throwing the tax revenues away would actually increase the long-run growth rate! ${ }^{21}$

The process of convergence to the new steady state is also quite different from that in a permanent boom economy. As can be seen from Figure VIII a, a permanent rise in $\sigma$ or a permanent fall in $\sigma_{2}$ shifts the ( $\left.\mathrm{S}^{\prime}\right)$ curve downward. As a result, $q$ falls initially and then continues to fall as it converges toward its steady-state level. Since, ceteris paribus, a fall in q raises the growth rate ${ }^{22}$ by shifting the distribution of wealth toward theinvestors, the initial rise in $\sigma$ or fall in $\sigma_{2}$ will end up having both a direct and indirect positive effect on the growth rate, as shown in Figure VIII b.

Similarly, Figures $\mathrm{IX}$ a and $\mathrm{IXb}$ show that the growthenhancing effects of a one-period increase in $\sigma$ or a one-period fall in $\sigma_{2}$ will also persist beyond the period of the shock. Moreover, there is the possibility of a multiplier: the output effect of a shock may be larger after the shock itself has died out and the economy has gone back to its original parameters. ${ }^{23}$ This is again due to the fact that the shock shifts the distribution of wealth in favor the

21. Alternatively, the government could impose interest rate ceilings so as to push the interest rate bel ow $\sigma_{2}$ (see Section IV below).

22. The growth rate in a slump period is given by $(1-\alpha)((\sigma / q)+(1-$ $\left.(1 / q) \sigma_{2}\right)$

23. Let $Y_{0}$ denote the average output of the economy before the shock, $Y_{1}$ denote the average output in the period when the shock hits, and $Y_{2}$ denote the average output in the following period right after the productivity parameter $\sigma$ has come back to its initial value. Assume that the economy is initially in a permanent slump. For a sufficiently small initial increase in productivity from $\bar{\sigma}$ to $\bar{\sigma}+\mathrm{d} \sigma$, one can show that

$$
\begin{aligned}
& \frac{\mathrm{Y}_{2}}{\mathrm{Y}_{1}}=\frac{1}{\mathrm{q}_{1}} \bar{\sigma}+\left(1-\frac{1}{\mathrm{q}_{1}}\right) \sigma_{2} \\
> & \frac{\mathrm{Y}_{1}}{\mathrm{Y}_{0}}=\frac{1}{\mathrm{q}_{0}}(\bar{\sigma}+\mathrm{d} \sigma)+\left(1-\frac{1}{\mathrm{q}_{0}}\right) \sigma_{2}>1,
\end{aligned}
$$

where $q_{0}$ and $q_{1}$ are the values of $q$ before and right after the shock; i.e.,

and

$$
\mathrm{q}_{0}=\gamma(\bar{\sigma}) \cdot\left[\bar{\sigma}-\sigma_{2}+\sigma_{2} \mathrm{q}_{0}\right]=\mathrm{s}
$$

$$
\mathrm{q}_{1}=\gamma(\bar{\sigma}+\mathrm{d} \sigma)\left[\bar{\sigma}+\mathrm{d} \sigma-\sigma_{2}+\sigma_{2} \mathrm{q}_{0}\right]
$$

where $\gamma(\sigma)$ is the first term in the expression for $\mathrm{q}^{\mathrm{t}+1}$ in equation $\left(\mathrm{S}^{\prime}\right)$ above. 


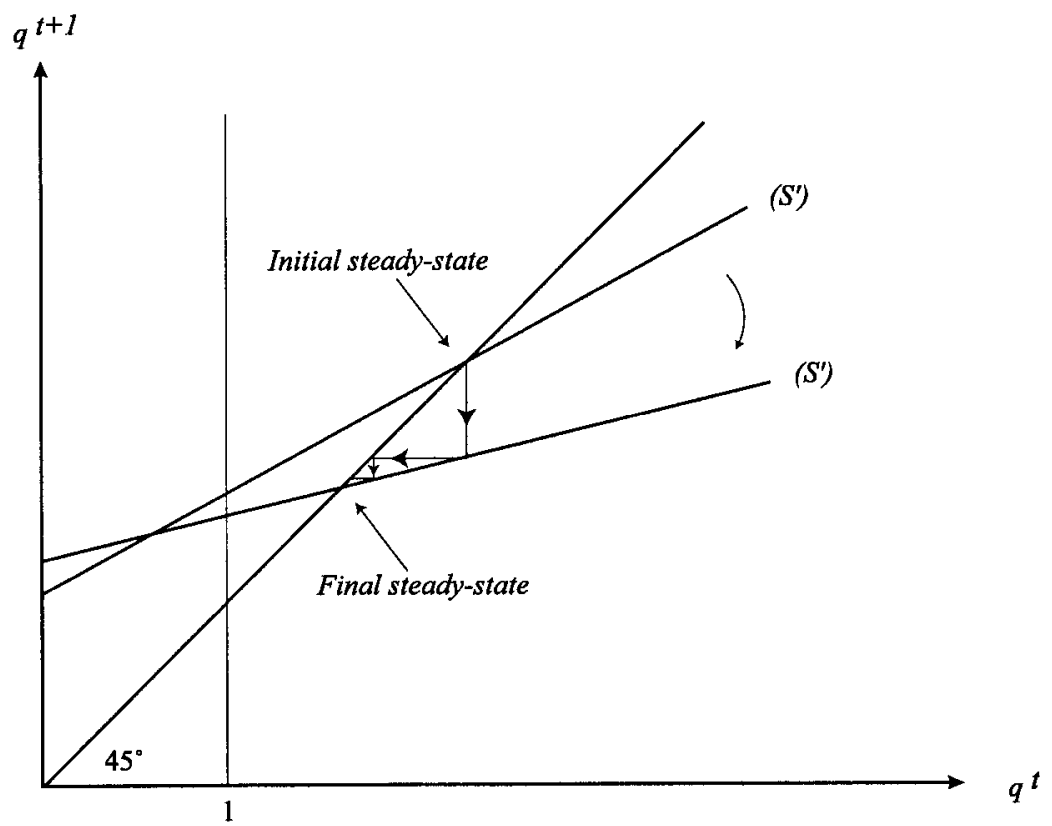

Figure VIIIa

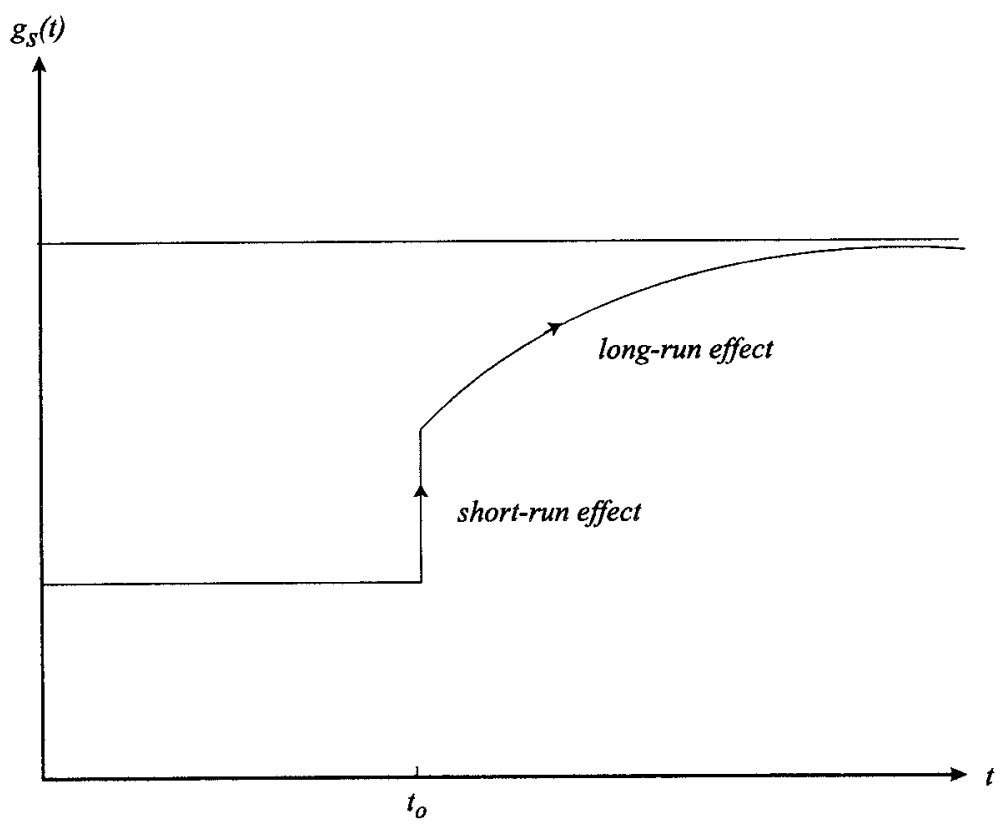

Figure VIII b

FIGURE VIII: Effect of a Permanent Increase in $\sigma$ on Economy in Slump 


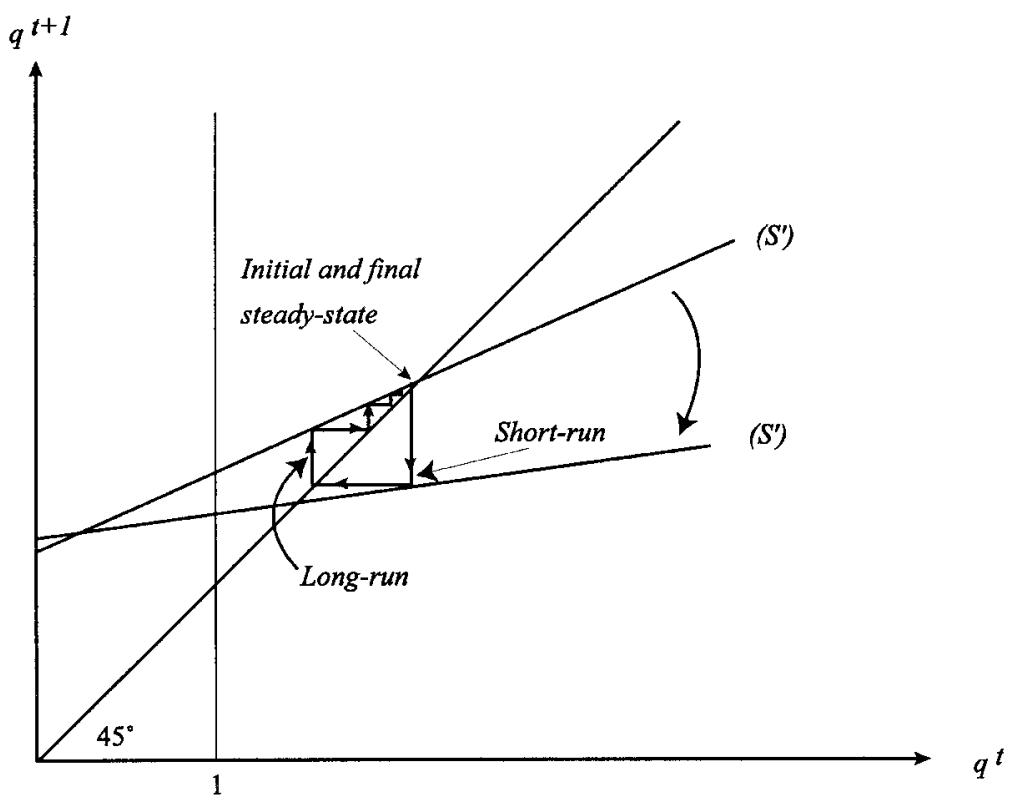

FIGURE IXa

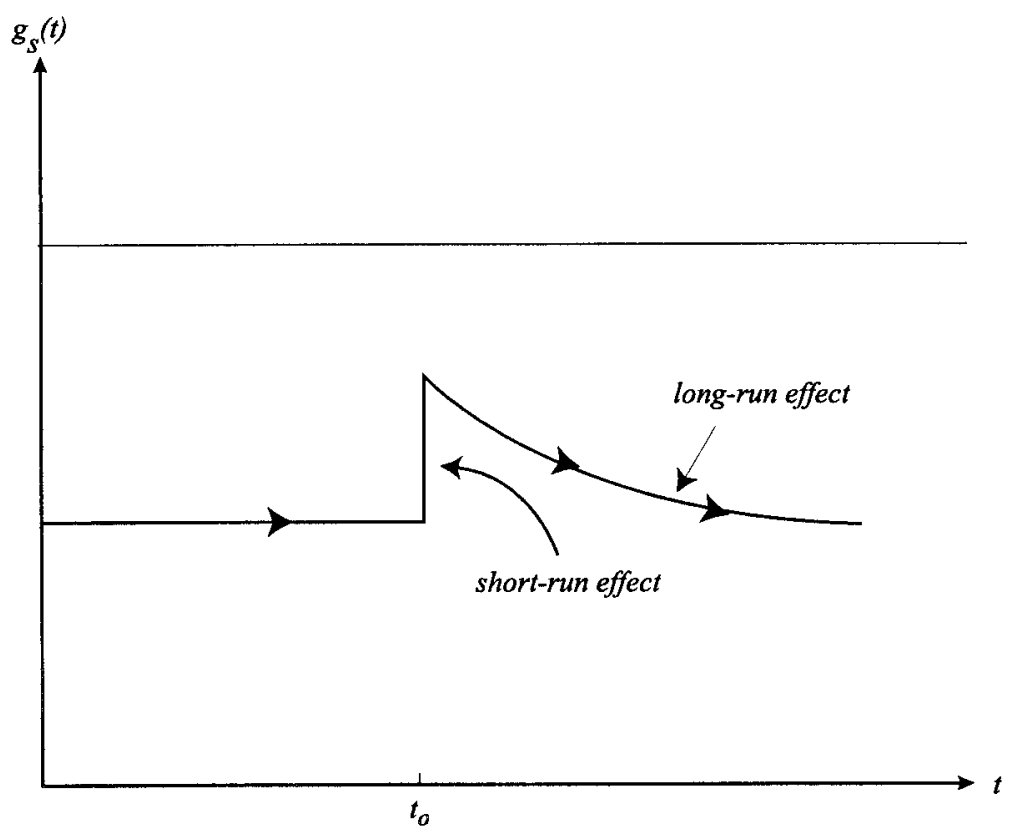

FIGURE IXb

FIGURE IX: Effect of a Temporary Increase in $\sigma$ on E conomy in Slump $g_{s}(t)$ responds nonmonotonically to temporary increase in $\sigma$, but it remains permanently above the preshock steady-state level. 
investors (i.e., shifts q down) and this distributional effect only dies away gradually.

The effects of shocks in a cyclical economy are, for obvious reasons, more complex. In particular, an increase in $\sigma$ has an ambiguous effect on average growth in this case: on the one hand, it increases growth during booms, but on the other hand, investors end up accumulating a higher debt burden during booms, which causes recessions to be more severe (i.e., with higher $q$ ratios in recessions). The overall effect on average growth is unclear in general. However, for the same reasons as in the permanent slump regime, an increase in $\sigma_{2}$ will have an unambiguously negative effect on average growth: a higher $\sigma_{2}$ leads to higher debt repayments during slumps and therefore both to lower growth during and al so to longer periods of slumps.

The process of convergence to the new cycleafter a permanent shock is potentially quite complicated (as the reader can readily verify by moving the ( $\mathrm{S}^{\prime}$ ) curve in Figures IV, V, or VI) and defies a straightforward classification. However, what remains unambiguously true is that unlike in the permanent boom case, the growth rate will only gradually adjust to its new steady-state level.

The above analysis ruled out the possibility that the shock results in shifting the economy from one of our regimes to another. As is evident from the condition for the cycling case, $\beta+(1-$ $\beta) \mu>v+\left(\sigma_{2} / \sigma\right)(1-v)$, high values of $\sigma$ and low values of $\sigma_{2}$, tend to move the economy away from a permanent slump toward a cycle. This is not necessarily a good thing: it turns out that an increase in $\sigma$ can actually reduce average growth by forcing the economy to shift from a permanent slump regime to a cyclical regime because at least over some open parameter interval, it is better never to have a boom than to have it some of the time. ${ }^{24}$

\section{III.4 Robustness of our Results}

Our results are derived in an exceedingly pared-down model, and it is legitimate to wonder whether these results would survive

24. Namely, assume that $\mu<v$ and consider $\sigma=\sigma^{*}$ such that $\mu(1-\beta)+\beta=$ $\nu+\left(\sigma_{2} / \sigma^{*}\right)(1-v)$. If $\sigma<\sigma^{*}$, the economy is in a permanent slump regime. As $\sigma \rightarrow$ $\sigma^{*}$, the permanent slump growth rate increases: $g_{s} \rightarrow g^{*}=(1-\alpha)_{\sigma}$. But if $\sigma$ goes above $\sigma^{*}$, then the economy exits the permanent slump regime and begins to cycle: that is, the average growth rate falls bel ow its Harrod-Domar value. It follows that at least over some range $\left[\sigma^{*}, \sigma^{*}+\epsilon\right]$, the average growth rate is a decreasing function of $\sigma$ (although there need not exist any discontinuity in average growth rates). F or the same reasons, the average growth rate is an increasing function of $\sigma_{2}$ at least over some range $\left[\sigma_{2}^{*}-\epsilon, \sigma_{2}^{*}\right]$, in the region where an increase in $\sigma_{2}$ shifts the economy from a cyclical regime to a permanent slump. 
in a more realistic model. Here we make a number of comments emphasizing the directions in which the model can be extended without losing our basic results.

1. In the present version of the model, the equilibrium interest rate $r$ fluctuates discontinuously between one high value and one low value. In a previous version of the paper we constructed a version of the model where investors can choose among a continuum of technologies and therefore where the equilibrium interest rate can take on a continuum of values and showed that we still get cycles.

2. If consumption-savings decisions were taken at the beginning of the period instead of at the end, an expected fall in interest rates would reduce savings, limiting the fall in interest rates and thereby limiting the extent of fluctuation. However, if this were to eliminate all fluctuations, the interest elasticity of savings would have to be quite high, which it does not seem to be [Attanasio and Weber 1993]. The same comment applies to whether our result will change if savers are forward-looking.

3. Throughout our analysis in this paper, we have assumed that individuals with investment opportunities have the same propensity to consume as those with no investment opportunities. Introducing different savings rates $\left(1-\alpha_{L}\right)$ and $\left(1-\alpha_{B}\right)$ for lenders and borrowers would slightly complicate the analysis of the model, but the essential conclusions would be unchanged. Moreover, using the fact that the slopes of the $\left(\mathrm{B}^{\prime}\right)$ and $\left(\mathrm{S}^{\prime}\right)$ curves are increasing functions of the ratio $\left(1-\alpha_{L}\right) /\left(1-\alpha_{B}\right)$, one can show $^{25}$ (i) if $1-\alpha_{B} \ll 1-\alpha_{L}$, then the economy converges to a permanent slump as borrowers' investment can never absorb the total amount of lenders' savings; (ii) if $1-\alpha_{L} \ll 1-\alpha_{B}$, then the economy converges to a permanent boom, as borrowers' investment capacity tends al ways to be greater than aggregate savings $\left.\left(W_{B} / \gamma>W_{B}+W_{L}\right)\right)$; (iii) in the intermediate case where $\left(1-\alpha_{L}\right)$ and $\left(1-\alpha_{B}\right)$ are of comparable magnitudes, the economy will converge to a limit cycle for suitable values of the parameters. In this case we can analyze how the characteristics of the limit cycle are affected by the relative savings rates of Ienders and borrowers. Intuitively, if $1-\alpha_{B}$ is relatively small compared with $1-\alpha_{L}$, then booms should be of short duration, and slumps should be longlasting, as it should take a while before borrowers can reconstitute their investment capacity following a credit crunch. Conversely, if

25. The reader can verify this by looking back at Figures $\mathrm{V}$ and $\mathrm{VI}$. 
$1-\alpha_{L}$ is small relative to $1-\alpha_{B}$, then booms will be long-lasting, and slumps will be short.

4. Even if investors were long-lived instead of living for just one period, in our model they never have a reason to postpone investment since investment always earns a higher return than the cost of capital $\left(r \leq \sigma_{1}\right)$. That is, while slumps are indeed the best period to invest (interest rates are low), investors have no reason to delay their investment until the next slump because they will always have more money to invest next period if they invest today. ${ }^{26}$

5. Our results clearly depend on the interest rate being endogenous and not given from outside, as it might be, for example, in a small open economy. However, this seems a reasonable approximation to the reality in many economies (see Feldstein and Horioka [1980] for evidence showing that capital tends not to move across borders). Furthermore, as we show in Aghion, Bacchetta, and Banerjee [1998], while opening a small economy with credit-constrained investors to foreign borrowing and lending, has the obvious effect of stabilizing interest rate movements, it may still destabilizethe economy by exacer bating movements in the real exchange rate. ${ }^{27}$

6. Throughout our analysis, we have taken the creditmultiplier $1 / v$ to be independent of the level of interest rates. In Appendix 1 we provide an explicit microeconomic derivation of this constant credit-multiplier, based on ex post moral hazard on the part of the borrower, combined with an appropriate choice of the lenders' monitoring technology. It is also possible to derive a credit multiplier from an ex ante moral hazard story à la

26. On the other hand, forward-looking firms may tend to accumulate savings at a higher rate during booms (e.g., by cutting dividends) in order to expand their investment in slumps. This would also tend to reduce the amplitude of the fluctuations, but it should not eliminate all fluctuations unless the shareholders of the firm are extremely patient.

27. The underlying mechanism is similar to the one described in this paper, except that the pecuniary externality which serves as the transmission variable for generating fluctuations, is the real exchange rate, defined as the price of nontradable goods in terms of the tradable good. More specifically, the basic mechanism in Aghion, Banerjee, and Bacchetta [1998] can be described as follows: suppose that high-yield investments in the domestic economy require the use of nontradable goods (such as real estate) as inputs to produce tradable goods. Then during a boom the domestic demand for nontradable goods keeps going up as high-yield investments build up, and thus so does the price of nontradables relative to that of tradables. This, together with the accumulation of debt that still goes on during booms, will eventually squeeze investors' borrowing capacity and therefore the demand for nontradable goods. At this point, the economy experiences a slump in which the price of nontradable goods collapses, and lendable funds flow out of the country. 
Holmstrom and Tirole [1997], but this would give us a v(r) which increases with the interest rate $r$. This, in turn, would tend to dampen investors debt buildup during booms and thereby reduce the magnitude of subsequent slumps. However, one can show that the occurrence of cyclical (or volatile) growth patterns is still preserved in this case so long as $v(r)$ does not increase too rapidly with $r{ }^{28}$

7. We show in Appendix 1 that our results are also robust to allowing investors and savers to write long-term debt contracts. Intuitively a long-term contract may allow borrowers to postpone a part of the repayment on their debt to periods when they expect to be relatively cash rich and thereby limit the variation in $\mathrm{q}^{\mathrm{t}}$. We show in Appendix 1 that while this intuition is correct, the economy will continue to have cycles under conditions that are somewhat stronger than those assumed in our basic model..$^{29}$

8. Two empirical predictions that emerge from our analysis are, first that the ratio of debt-obligations over cash flow should peak toward the end of booms, and second that the real interest rate paid by firms should be strongly procyclical. The first prediction appears to be directly and strongly supported by existing empirical evidence (e.g., see Eckstein and Sinai [1986] and Bernanke and Gertler [1995b]). The evidence on the second prediction, however, is less clear. The existing interest rate data for most developed countries show that the real interest rates on bonds of various maturities are only weakly procyclical (nominal rates, on the other hand, are strongly procyclical). On the other hand, it is well-known that rates on short-term debt always pass above long rates during booms, ${ }^{30}$ which, given the fact that the share of short-term debt tends to go up at the end of booms, ${ }^{31}$ implies that the average interest rate paid by firms actually varies more strongly with the business cycle than either the long or the short rate ${ }^{32}$

However, even if one accepts that the movements in interest

28. This, in turn, is automatically the case in the Holmstrom-Tirole model when the marginal efficiency of effort, measured by the ratio of the increase in the probability of success over the effort cost required to achieve such an increase, is not too high.

29. Actually this result assumes that long-term contracts are no harder to enforce than short-term contracts. The conditions under which the economy cycles would be weaker if we were prepared to make the reasonable alternative assumption that long-term contracts are harder to enforce.

30. On this point see Stock and Watson [1997].

31. See Friedman and Kuttner [1993a, 1993b] for evidence on the shifts in the composition of firms' debt portfoli ios al ong the business cycle.

32. Friedman and Kuttner [1993a, 1993b] make a similar point. 
cost are as we claim here, one might question whether it is driven by the mechanism described here: it is possible, for example, that procyclical movements in interest costs are simply a result of monetary policy. ${ }^{33}$ One possible way to test our model while controlling for variations in the stance of monetary policy, is to look at interest rate spreads over the cycle. For example, Stock and Watson [1997] show that the spread between rates on unsecured commercial paper and the rate on (nondefaulting) treasury bills, increases sharply toward the end of booms, and then decreases during slumps. ${ }^{34}$ This is consistent with our model where one can interpret $\sigma_{2}$ as the rate of interest on government bonds (assuming that the supply of bonds is infinitely elastic), whiler is the interest rate on commercial paper.

\section{Policy Analysis}

What can a government do in the context of our model in order to limit the extent of cyclical fluctuations and the length of suboptimal growth periods associated to slumps?

The ultimate source of the instability and the associated inefficiency highlighted in this paper is inequality in the access to the most rewarding investment opportunities-what we have called dualism. An obvious policy response would be to reduce the extent of dualism in the economy: if the government could improve access to credit (reduce $v$ ) or access to direct investment opportunities in production (increase $\mu$ ) so that $\mu>v$, then the economy would switch to a regime of permanent boom and no slump would ever occur in the long run (Figure III). This argues for emphasizing policies which improve credit access, create infrastructure and human capital in areas where such things are missing and reduce barriers to entry. Therefore, our model suggests that the issue of macroeconomic stabilization should not be examined separately from the issue of structural reforms: removing the institutional obstacles and rigidities that separate savers and investors can promote growth, stability, and equity at the sametime.

It is worth stressing that the immediate policy prescription of

33. This is, for example, the view taken by Eckstein and Sinai [1982].

34. Bernanke, Gertler, and Gilchrist [1998] perform a VAR estimation of the impulse response to monetary shocks, and find that the spread between the rates on commercial paper and on T-bills widens in response to a negative monetary shock. 
this model is the improvement of access to investment opportunities for savers, which is not the same thing as the more broadbased promotion of equity emphasized, for example, in many of the recent papers on inequality and growth. ${ }^{35}$ The difference comes from the fact that the people who have the most savings to invest are not necessarily poor and probably do not include the very poor: policies that are targeted at savers may not promote overall equity at least in the short run. ${ }^{36}$

However, such structural policies may be difficult to implement (especially in the short run), and in some cases they are just not feasible: governments cannot simply decide that access to credit and investment opportunities should be extended. I nterestingly, our model also allows us to explore the effects of more conventional countercyclical macroeconomic policies. Our theory of business fluctuations describes slumps as periods where a positive fraction of savings are not being used efficiently ("idle" savings) because of the investors' limited borrowing capacity. Assuming that the structural parameters of the model cannot be changed, the obvious way to prevent the occurrence of recessions would be to transfer those idle savings from savers to investors whenever necessary. That is, if at the beginning of some period $t$ the investment capacity $\mathrm{W}_{\mathrm{B}}^{\mathrm{t}} / \nu$ of investors is smaller than the total amount $\mathrm{W}_{\mathrm{L}}^{\mathrm{t}}+\mathrm{W}_{\mathrm{B}}^{\mathrm{t}}$ of available savings (i.e., $\mathrm{q}^{\mathrm{t}-1}=v\left(\mathrm{~W}_{\mathrm{L}}^{\mathrm{t}}+\right.$ $\left.\left.W_{B}^{t}\right) / W_{B}^{t}>1\right)$, then in order to achieve the Harrod-Domar rate of growth it is sufficient to redistribute wealth $\mathrm{dW}$ from savers to investors such that

$$
\left(\mathrm{W}_{\mathrm{B}}^{\mathrm{t}}+\mathrm{dW}\right) / \nu=\mathrm{W}_{\mathrm{L}}^{\mathrm{t}}+\mathrm{W}_{\mathrm{B}}^{\mathrm{t}}
$$

This policy ensures that all available savings will be invested in the high-yield activity, and therefore that output will grow at rate $(1-\alpha)_{\sigma}$. Moreover, note that such a growth-enhancing countercyclical policy does not necessarily entail negative distributive consequences for savers. First, the wealth transfer dW will boost the demand for investment credit and therefore will raise the equilibrium interest rate from its depressed value $\sigma_{2}$ to its high value $\sigma_{1}=\beta \sigma>\sigma_{2}$. Therefore, the interest income of savers shifts from $\sigma_{2} \mathrm{~W}_{\mathrm{L}}^{\mathrm{t}}$ to $\sigma_{1}\left(\mathrm{~W}_{\mathrm{L}}^{\mathrm{t}}-\mathrm{dW}\right)$. In particular, if the required

35. See Bénabou [1996] for a survey.

36. Nothing in our model would change if we added a class of poor agents in the economy who never save anything and therefore have no wealth whatsoever, although this would increase inequality as it is usually measured. This distinguishes our model from political economy models in which the have-nots often play a crucial role. 
wealth transfer $\mathrm{dW}$ is small, (i.e., if the coming recession is not too severe or, more formally, if we start with $\mathrm{q}^{\mathrm{t}-1}$ close to 1 ), then the interest income of savers is higher with the expansionary wealth transfer dW than without it, especially if $\sigma_{2}$ is small relative to $\sigma_{1} \cdot 37$

In addition, if the wage rate in this economy has an efficiency wage component (so that employed workers earn some rents) the wealth transfer dW can also benefit the noninvestors because of its expansionary effects on the labor market. The explicit calculations for this case are given in a previous version of this paper.

In practice, a countercyclical wealth transfer policy need not take the form of redistributive wealth taxation: the same goals can be achieved more easily through expansionary monetary and fiscal policies. One natural interpretation of expansionary monetary policy in the context of our model is that during periods where the limited borrowing capacity of investors forces the economy to enter in a recession, monetary authorities may decide to print money and give it to overindebted businesses. Given the resulting increase in the price level, this is equivalent to a real transfer dW from savers to investors, and will have the same effects as described above. ${ }^{38}$

Our model also delivers a very natural interpretation of countercyclical fiscal policies: since slumps are periods with idle savings, governments can promote recovery by issuing public debt in order to absorb those idle savings and finance investment subsidies (or tax cuts for businesses). That is, at the beginning of any period $t$, where there are excess savings and the economy is about to enter a recession $\left(\mathrm{q}^{\mathrm{t}-1}>1\right)$, the government should issue new public debt $\mathrm{dB}$ and use the proceeds to finance investment subsidies or tax cuts dT for investors. As long as government bonds yield a return at least equal to $\sigma_{2}$, savers will be willing to lend their money to the government in order to financethis wealth transfer to investors. If public debt repayment at the end of the

37. The reason why private actors do not implement this wealth transfer themselves is obviously because in this perfectly competitive environment they do not internalize the aggregate effect of such transfers on the price of capital. N ote also that this interest rate effect is not always strong enough to compensate the savers for the extra taxes they pay: for example, if $v=1$, i.e., if the savers need to transfer all their wealth to investors in order to ensure Harrod-Domar growth, then their interest income will unambiguously fall.

38. Although this crude type of monetary policy is by no means unheard of, this is not the way modern central banks usually intervene (at least in western countries). Qualitatively, it is likely, however, that more standard interventions (such as lowering the discount rate bel ow the equilibrium interest rate level) will also result in the same net real transfer from lenders to borrowers. 
period is financed out of general tax revenues, then this countercyclical fiscal policy is equivalent to a direct wealth transfer dW from savers to investors. In fact, in the extreme case where the increase $\mathrm{dB}$ in public debt at $\mathrm{t}^{-}$used to finance the investment subsidy or tax cut $\mathrm{dW}=\mathrm{dB}$ is paid back at $\mathrm{t}^{+}$by a tax hike $\mathrm{dT}=$ $\sigma_{2} \mathrm{~dB}$ falling entirely on the labor income or interest income of savers, both policies are exactly equivalent. In particular, under the conditions described above, such a countercyclical fiscal policy can be in everybody's interest (including the savers) because of its expansionary effects on both interest and labor income. ${ }^{39}$

Finally, note that such a countercyclical transfer policy may have to be permanently sustained. In particular, when the government tries to prevent a recession at $\mathrm{t}^{-}$by lowering the savings/investment ratio $\mathrm{q}^{\mathrm{t}-1}$ from its laissez-fairevalue $(\tilde{q}>1)$ to 1 (through the wealth transfer $\mathrm{dW}$ ), the equilibrium interest rate goes up from $r_{t}=\sigma_{2}$ to $r_{t}=\sigma_{1}$, which in turn implies that the savings/investment ratio $\mathrm{q}^{\mathrm{t}}$ next period will be higher than $1 .{ }^{40} \mathrm{In}$ other words, if the government stops intervening in period $t+1$, the economy will fall into a recession in the following period: the effect of the period-t countercyclical policy is then just to postpone the recession from period t to period $t+1$. In order to guarantee permanent Harrod-Domar growth rates (and to raise everybody's welfare under the conditions described above), the government will need to implement a permanent policy regime of wealth transfers from savers to investors at the beginning of each period (e.g., via investment subsidies). One al ternativestrategy would be to overshoot in period $\mathrm{t}^{-}$, i.e., to implement a wealth transfer $\mathrm{dW}$ higher than the required minimum amount, so as to push $\mathrm{q}^{\mathrm{t}-1}$ bel ow 1 and thereby ensure that the boom will continue in period $t+1$. This would allow the government to achieve a permanently high growth rate through policy interventions that remain only

39. If the government had a higher administrative and legal ability than lenders in terms of enforcing debt repayments, then an expansionary fiscal policy would be in the savers' interest even in the absence of the induced expansionary effects on interest and labor income: public debt could be paid back at $\mathrm{t}^{+}$by raising taxes only on investors, which in effect would amount to substitute public lending to investors for incentive-constrained private lending. However, if the government faces the same incentive constraints as private lenders, this is not feasible. For example, in the context of the simple credit market model described in Appendix 1 , a tax on investors' income would induce investors to default in case the tax is too high, and in any case would amount to a reduction in $\sigma$ and therefore to a lower credit multiplier (unless the government can tax investors while making sure that they do not shirk on their other obligations).

40. Solong as we were not in a permanent boom regime (in which case there is no policy issue), $\mathrm{q}^{\mathrm{t}+1}\left(\mathrm{q}^{\mathrm{t}}=1, \mathrm{r}_{\mathrm{t}+1}=\sigma_{1}\right)>1$ (see Section III and Figures II-IV). 
periodic. Another option would be to enforce interest rate ceilings at period $\mathrm{t}^{-}$together with the wealth transfer $\mathrm{dW}$ : if the government can ensure that the interest rate paid by investors does not go up all the way to $\sigma_{1}$, then the boom could be maintained forever without further policy interventions. ${ }^{41}$

\section{Appendix 1: A Model of the Capital Market}

\section{Basic Mode}

In this subsection we outlinea simple microeconomic model of (imperfect) lending that generates a constant credit multiplier $1 / v$ of the kind assumed in the paper.

Consider a borrower who needs to invest $\mathrm{W}+\mathrm{L}=\mathrm{I}$ in the high-yield technology, where $\mathrm{W}$ denotes his/her initial wealth and $L$ his/her requested loan. The source of capital market imperfection is ex post moral hazard and costly state verification. Namely, once the return $\sigma(W+L)$ is realized, the borrower can either repay immediately and get a net income equal to $\sigma(W+L)-r L$, or he/she can stall. Stalling revenues away from the lender has a cost to the borrower (who has to keep ahead of the lender), and let this cost be a fixed proportion $\tau$ of total revenues. Finally, whenever the borrower defaults on his/her repayment obligation, the lender may still invest effort into debt collection. Specifically, assume that a lender who incurs a nonmonetary effort cost $\mathrm{L} \cdot \mathrm{C}(\mathrm{p})$ has probability $\mathrm{p}$ of collecting her due repayment $r \cdot \mathrm{L} .{ }^{42}$

41. In the case of persistent volatility (Figure IV), we have $\mathrm{q}^{\mathrm{t}+1}\left(\mathrm{q}^{\mathrm{t}}=1\right.$, $\left.r_{\mathrm{t}+1}=\sigma_{1}\right)>1$ and $\mathrm{q}^{\mathrm{t}+1}\left(\mathrm{q}^{\mathrm{t}}=1, \mathrm{r}_{\mathrm{t}+1}=\sigma_{2}\right)<1$ (see Section III). By continuity, it follows that there exists some interest rate $\left.r^{*} \in\right] \sigma_{2}, \sigma_{1}\left[\right.$ such that $q^{t+1}\left(q^{t}=1\right.$, $\left.r_{t+1}=r^{*}\right)=1$. If the government sets an interest rate ceiling less than or equal to $r^{*}$, the economy will remain in a permanent boom. In the case of a permanent slump regime (Figure III), the government would need to set an interest rate ceiling below $\sigma_{2}$. Interest rate ceilings in the presence of excess demand for investible funds can obviously entail nonnegligible costs: when it is enforced successfully, we risk losing the benefits of the price as a screening device (in the model everyone is identical, but in the world some investors are better than others and the price mechanism plays an important screening role).

42. Here, we are implicitly assuming that debt repudiation is not verifiable by outsiders, so that the lender's ex post revenue cannot be made contingent upon whether default took place or not. This in turn explains why the lender cannot collect more than $r \cdot L$, even following a strategic default by the borrower. Alternatively, if we had assumed that lenders can sign debt contracts allowing them to collect everything in case of strategic default (and successful monitoring), then the credit multiplier would al ways be a declining function of the interest rate (e.g., as in Holmstrom and Tirole [1995]) instead of being constant as in our model in this paper. As we argue below, having $v$ increase with $r$ would not dramatically affect our analysis. 
Anticipating a monitoring effort $\mathrm{p}$ from the lender, the borrower will decide not to (strategically) default if and only if

$$
\sigma_{1}(L+W)-r L \geq \sigma_{1}(1-\tau)(L+W)-p r L,
$$

or equivalently

$$
\mathrm{L}+\mathrm{W} \leq \frac{\mathrm{W}}{1-\left(\sigma_{1} \tau\right) /(\mathrm{r}(1-\mathrm{p}))} .
$$

N ow, turning to the choice of the optimal monitoring policy $p$, the lender will solve

$$
\max _{p}\{p \cdot r L-L \cdot C(p)\},
$$

so her optimal choice of $\mathrm{p}$ is given by the first-order condition,

$$
r=C^{\prime}(p) \text {. }
$$

In the special case, where $C(p)=-c \cdot \ln (1-p)$, we obtain

$$
r=c /(1-p) \text {, }
$$

so that the incentive-compatibility constraint (A1) becomes simply

$$
\mathrm{L}+\mathrm{W}=\mathrm{I} \leq(1 / v) \cdot \mathrm{W},
$$

where $v=1-\left(\sigma_{1} \tau / \mathrm{c}\right)$ is indeed independent of the interest rate.

The case where the credit multiplier $1 / v$ is constant is clearly a knife-edged case, and departing from the monitoring cost function $C(p)=-c \cdot \ln (1-p)$, one can get this multiplier to increase or decrease with $r$. If $1 / v$ increases with $r$, then the interest rate will increase during booms and then drop down to $\sigma_{2}$ as investment demand falls below savings (which in turn will happen sooner than before as debt-repayment obligations build up faster than in the case where $v$ is constant). On the other hand, if $1 / v$ decreases with $r$, then the interest rate will decrease during booms which in turn will delay (and sometimes preclude ${ }^{43}$ ) the occurrence of recessions. For example, if $C(p)=\mathrm{cp}^{2} / 2$, we obtain the first-order condition,

$$
r(1-p)=r-\left(r^{2} / C\right)
$$

so that the incentive constraint (A1) becomes

$$
\mathrm{L}+\mathrm{W} \leq(1 / v(r)) \cdot \mathrm{W},
$$
booms 
where

$$
v(r)=1-\frac{\sigma_{1} \tau}{r-\left(r^{2} / c\right)}
$$

is increasing in $r$ whenever $r>(c / 2)$, thus in particular when $\sigma_{2}>(c / 2)$. we have

On the other hand, if $C(p)=\left(c(1-p)^{1-\theta}\right) /(1-\theta)$ with $\theta<1$,

$$
(\mathrm{W}) /(\mathrm{L}+\mathrm{W})=v(\mathrm{r})=1-\tau \mathrm{r}^{(1-\theta) / \theta} \mathrm{C}^{\mathrm{I} / \theta},
$$

which is decreasing in $r$, so that $1 / v(r)$ increases in $r$.

Remark 1. If credit rationing was due to ex ante rather than to ex post moral hazard (e.g., as formalized in Holmstrom and Tirole [1997]), then $v(r)$ would increase with $r$, but one can show that it will not increase too rapidly when the marginal efficiency of effort, measured by the ratio of the increase in the probability of success over the effort cost required to achieve such an increase, is not too high. The occurrence of cyclical (or volatile) growth patterns will then be preserved.

Remark 2. One can interpret the increasing relationship between $v$ and $r$ in Holmstrom and Tirole [1997] as a weal th effect: namely, the lower the interest rate $r$, the higher the discounted value of future (i.e., end-of-period) profits and thereforethe higher the current borrowing capacity of investors. Our microeconomic derivation of a constant multiplier $1 / v$ eliminates this wealth effect by introducing a second effect that offsets it exactly. Namely, a lower interest rate reduces the per dollar benefit of lenders' ex post monitoring effort in collecting debt-repayment from their borrowers. This in turn reduces the maximum amount $L$ which lenders are willing to lend to borrowers with given current wealth $W$; i.e. it reduces the credit multiplier $1 / v$. Our choice of ex post monitoring technology $C(p)=-c \cdot \ln (1-p)$ generates a constant multiplier $v$ by having the above two effects of $r$ on investors' borrowing capacity exactly cancel out.

\section{Long-Term Debt Contracts}

In this subsection we investigate the effects of introducing long-term credit contracts into our basic model. I ntuitively, a long-term contract may allow borrowers to postpone a part of the repayment on their debt to periods when they expect to be relatively cash rich and thereby limit the variation in $\mathrm{q}^{\mathrm{t}}$. Here we 
ask whether such intertemporal substitution can eliminate the cycle we get in our basic model.

Consider an extension of the above model where agents live for two periods instead of one period but each new generation is only born when the previous generation dies (i.e., it is a nonoverlapping generation model). F or simplicity we al so assume (a) that in the absence of long-term lending, the economy converges to a two-cycle; (b) that agents (borrowers and lenders) do not care about consumption smoothing and therefore may as well consume everything at the end of their two-period life. During a current boom, young borrowers might then be interested in signing a two-period debt contract with their lending counterparts whereby a "current" rate $r_{1}<\sigma_{1}$ would be paid at the end of the first period and a future rate $r_{2}>\sigma_{2}$ would be paid at the end of the second period. Borrowers may al so engage in further short-term borrowing during the second period.

The borrower's incentive constraint at the end of the first period will be

$$
\sigma_{1}\left(L_{1}+W\right)-r_{1} L_{1} \geq \sigma_{1}(1-\tau)\left(L_{1}+W\right)-p r_{1} L_{1},
$$

where $L_{1}$ is the long-term debt contracted at the beginning of period 1 and where $r_{1}(1-p)=c$ under the same monitoring technol ogy as the one postulated in the above subsection.

The above incentive-constraint can then be reexpressed as in (i) above, namely,

$$
\mathrm{L}_{1}=((1 / v)-1) \mathrm{W}
$$

where $v=1-\left(\sigma_{1} \tau\right) / c$.

The borrower's accumulated cash net of current debt repayment-at the end of period 1-will be equal to

$$
\hat{W}=\sigma_{1} W+\left(\sigma_{1}-r_{1}\right) L_{1} .
$$

However, the borrower will not be able to invest up to the amount $\hat{W} / v$ simply because $\hat{W}$ does not reflect his true wealth at the beginning of period 2 . Short-term lenders in period 2 will indeed take into account the existence of further outstanding debtrepayment obligations toward long-term lenders.

More formally, if $L_{2}$ denotes the additional amount to be borrowed short term in period 2, the borrower's incentive constraint at the end of that period is written as 
(A3)

$$
\begin{aligned}
& \sigma_{1}\left(\sigma_{1} W+\left(\sigma_{1}-r_{1}\right) L_{1}+L_{2}\right)-r_{2}^{*} L_{2}-r_{2} L_{1} \\
& \geq \sigma_{1}(1-\tau)\left(\sigma_{1} W+\left(\sigma_{1}-r_{1}\right) L_{1}+L_{2}\right)-p_{2} \cdot r_{2}^{*} L_{2}-p_{1} r_{2} L_{1},
\end{aligned}
$$

where, if we stick to the same debt-monitoring technology as before,

$$
r_{2}^{*}\left(1-p_{2}\right)=r_{2}\left(1-p_{1}\right)=c
$$

Using (A4) to eliminate $p_{1}, p_{2}, r_{2}$, and $r_{2}^{*}$ in the incentiveconstraint (A3), we end up reexpressing (A3) as

$$
\sigma_{1} W+\left(\sigma_{1}-r_{1}\right) L_{1}+L_{2} \geq\left(c / \tau \sigma_{1}\right)\left(L_{1}+L_{2}\right) \text {. }
$$

Now if $r_{1}=0$ (which corresponds to the best long-term contract candidate for maximizing the borrowing capacity $L_{2}$ and thereby possibly delaying the occurrence of a slump), the above incentive constraint becomes

$$
\mathrm{L}_{2} \leq \frac{\sigma_{1} \mathrm{~W}+\left(\sigma_{1}-\left(c / \tau \sigma_{1}\right)\right) \mathrm{L}_{1}}{\left(c / \tau \sigma_{1}\right)-1}
$$

Using (A2') to substitute for $L_{1}$, we get

$$
\mathrm{L}_{2} \leq \Omega \cdot \mathrm{W},
$$

where

$$
\Omega=\frac{1}{v}\left(\sigma_{1} \frac{1}{v}-\left(\frac{1}{v}-1\right)\right)=\beta \sigma \frac{1}{v}-\left(\frac{1}{v}-1\right) .
$$

Whenever $\Omega<\sigma$, which, in particular, will be the case for $\beta$ sufficiently small and $v$ sufficiently close to 1 , then it will still be the case that investment capacity will grow at a lower rate than savings grows in a boom, so that even if we allow for long-term debt contracts the occurrence of slumps will remain unavoidable. However, note that allowing for long-term debt contracts may increase the borrower's investment capacity as compared with the pure short-term borrowing case and yet not to a sufficient extent that the occurrence of slumps can be avoided: for example, for $v$ close to 1,

$$
\underbrace{(1 / \nu) \sigma_{1} \mathrm{~W}}_{\begin{array}{c}
\text { investment capacity } \\
\text { under short-term } \\
\text { borrowing }
\end{array}}<\underbrace{\Omega \cdot \mathrm{W}}_{\begin{array}{c}
\text { investment capacity } \\
\text { under long-term } \\
\text { bargaining }
\end{array}} \text { but still } \Omega<\sigma \text {. }
$$




\section{Appendix 2: Comparison With the Goodwin Model}

Here we show how our model can easily be extended in order to offer a micro-founded version of Goodwin's [1967] model of growth cycles.

Assume that the interest rate is permanently equal to $r^{*} \in$ $\left[\sigma_{1} ; \sigma_{2}\right]$ (if world capital markets were perfectly integrated, $r *$ could simply be the world real interest rate). In order to generate fluctuations in the profit share, assume for simplicity a Leontief production function: $Y=\sigma \min (K, L)$. Assume that $\mu=0$ (only business profits can be directly invested in production) and that the labor supply schedule is such that the wage rate $v$ can take only two equilibrium values: if $v=v_{1}=(1-\beta)_{\sigma}$, then labor supply (in efficiency units) grows at a rate $\mathrm{n}$ from the previous period, and if $v=v_{2}=\left(1-\beta^{\prime}\right) \sigma$ (with $\beta^{\prime}<\beta$ and $v_{2}>v_{1}$ ), then labor supply grows at a rate $\mathrm{n}(1+\mathrm{a})$ (say that workers accept working extra hours if they are paid a higher wage).

It follows that if $\mathrm{g}_{\mathrm{t}}\left(=\mathrm{K}_{\mathrm{t}} / \mathrm{K}_{\mathrm{t}-1}\right)<\mathrm{n}$, then $\mathrm{v}_{\mathrm{t}}=\mathrm{v}_{1}, \mathrm{~W}_{\mathrm{t}}^{\mathrm{B}}=\mathrm{g}_{\mathrm{r}^{*}}$. $\mathrm{W}_{\mathrm{t}-1}^{\mathrm{B}}$, with $\mathrm{g}_{\mathrm{r}^{*}}=(1-\alpha)\left(\beta \sigma+\left(\beta \sigma-\mathrm{r}^{*}\right)((1 / v)-1)\right.$ and $\mathrm{g}_{\mathrm{t}+1}=\mathrm{g}_{\mathrm{r} *}$. Conversely, if $g_{t}>n$, then $v_{t}=v_{2}, W_{t}^{B}=g_{r *}^{\prime} W_{t-1}^{B}$, with $g_{r^{*}}^{\prime}=$ $(1-\alpha)\left(\beta^{\prime} \sigma+\left(\beta^{\prime} \sigma-r^{*}\right)((1 / v)-1)\right.$, and $g_{t+1}=g_{r^{*}}^{\prime}$. Therefore, if we assume that $\mathrm{g}_{\mathrm{r} *}^{\prime}<\mathrm{n}<\mathrm{g}_{\mathrm{r} *}<\mathrm{n}(1+\mathrm{a})$, there exists a two-period cycle with $g_{2 t}=g_{r *}^{\prime}, v_{2 t}=v_{1}$ and $g_{2 t+1}=g_{r *}, v_{2 t+1}=v_{2}$ : booms contain the seeds of their own destruction becausetheimplied rise in wage rates reduces businesses' future ability to invest (and conversely for recessions). Unlike in our model, the capital share of output is countercyclical (it fluctuates between $\beta$ and $\beta^{\prime}$ ). However, note that in both models, the net-of-debt-payments profit share of capital income (and of output) is countercyclical, and it is the leading indicator of economic fluctuations.

UnIVERSiTy College, LoNDON, AND EBRD, LONDON DEPARTMENT OF ECONOMICS, MASSACHUSETTS INSTITUTE OF TECHNOLOGY CEPREMAP AND CNRS, PARIS

\section{REFERENCES}

Aghion, P., P. Bacchetta, and A. Banerjee, "Capital Markets and the Instability of Open Economies," unpublished, University College of London and Harvard University, 1998.

Aghion, P., and P. Bolton, "A Trickle-Down Theory of Growth and Development," Review of Economic Studies, LXIV (1997), 151-172.

Attanasio, O., and G. Weber, "Consumption Growth, the Interest Rate and Aggregation," Review of E conomic Studies, LX (1993), 631-649.

Banerjee, A., and A. N ewman, "Occupational Choice and the Process of Development,"J ournal of Political E conomy, CI (1993), 274-298. 
Bénabou, R., "Inequality and Growth," in NBER Macroeconomics Annual 1996 (Cambridge: MIT Press, 1996), pp. 11-74.

Bernanke, B., and M. Gertler, "Agency Costs, Net Worth and Business Fluctuations," in Business Cycle Theory, F. Kydland, ed. (Cheltenham, UK: Ashgate, 1995a), pp. 197-214.

Bernanke, B., and M. Gertler, "Inside the Black Box: The Credit Channel of Monetary Policy Transmission,"J ournal of E conomic Perspectives, IX (1995b), 27-48.

Bernanke, B., M. Gertler, and S. Gilchrist, "The Financial Accelerator in a Quantitative Business Cycle Framework," NBER Working Paper No. 6455, 1998.

Eckstein, O., and A. Sinai, "The Mechanisms of the Business Cycle in the Postwar Era," in TheAmerican Business Cycle: Continuity and Change, R. Gordon, ed. (Chicago: University of Chicago Press, 1986), pp. 39-105.

Fazzari, S., G. Hubbard, and B. Petersen, "Financial Constraints and Corporate Investment," Brookings Papers on E conomic Activity, No. 1 (1988), 141-195.

Fazzari, S., and B. Petersen, "Working Capital and Fixed Investment: New Evidence on Financial Constraints,"Rand J ournal of E conomics, XXIV (1993), 328-342.

Feldstein, M., and C. Horioka, "Domestic Saving and I nternational Capital Flows," Economic J ournal, XC (1980), 314-329.

Fisher, I. "The Debt-Deflation Theory of Great Depressions," Econometrica, I (1933), 337-357.

Frankel, M.," "The Production Function in Allocation and Growth: A Synthesis," American E conomic Review, LII (1962), 995-1022.

Freixas, X., and J . Rochet, Microeconomics of Banking (Cambridge: MIT Press, 1997).

Friedman, B., and K. Kuttner, "Why Does the Paper-Bill Spread Predict Real Economic Activity?" in Business Cycle Indicators and Forecasting, J. Stock, and M. Watson, eds. (Chicago: University of Chicago Press, 1993a), pp. 213-249.

Friedman, B., and K. Kuttner, "Economic Activity and the Short-Term Credit Markets: An Analysis of Prices and Quantities," Brookings Papers on Economic Activity, No. 2 (1993b), 193-283.

Galor, O., and J . Zeira, "I ncome Distribution and Macroeconomics," Review of Économic Studies, ĹX (1993), 35-52.

Goodwin, R. M. "A Growth Cycle," in C. Feinstein, ed., Capitalism and Economic Growth (Cambridge: Cambridge University Press, 1967).

Haberler, G., Prosperity and Depression (London: Allen and Unwin, 1964).

Harrod, R., "An Essay in Dynamic Theory,"E conomic) ournal, XLIX (1939), 14- 33.

Holmstrom, B., and J. Tirole, "Financial I ntermediation, Loanable Funds and the Real Sector," Quarterly J ournal of Economics, CXII (1997), 663-691.

Honkapohja, S., and E. Koskela, "The Economic Crisis of the 1990s in Finland," unpublished, Economic Policy Forum, October, 1998.

Keynes, J., The General Theory of Employment, Interest and Money (New York: Harcourt and Brace, 1936).

Kiyotaki, N., and J. Moore, "Credit Cycles," J ournal of Political Economy, CV (1997), 211-248.

Piketty, T., "The Dynamics of the Wealth Distribution and Interest Rate with Credit Rationing,"Review of E conomic Studies, LXIV (1997), 173-189.

Romer, P., "Increasing Returns and Long-Run Growth," J ournal of Political Economy, XCIV (1986), 1002-1037.

Stock, J., and M. Watson, "Business Cycle Fluctuations in U. S. Macroeconomic Time Series," unpublished, Harvard and Princeton Universities, 1997. 